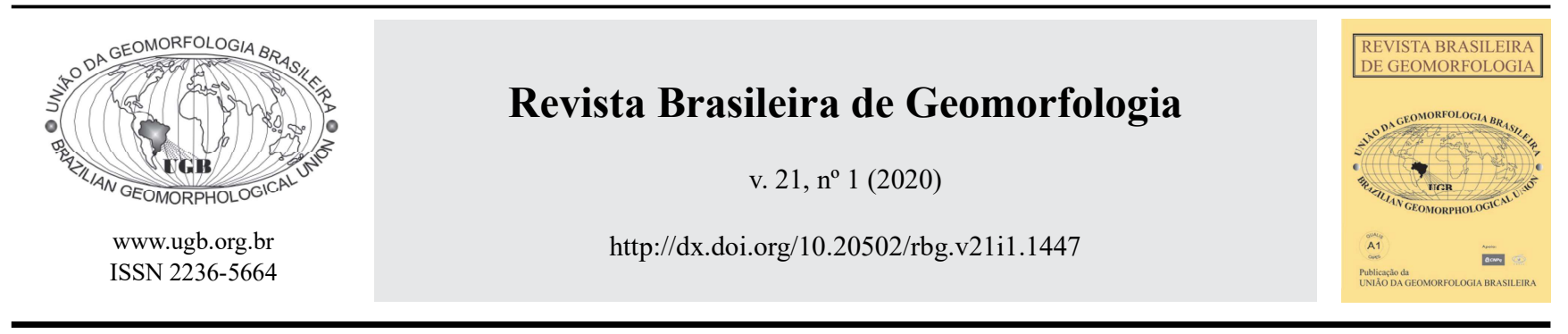

\title{
GEOMORFOLOGIA DO NORDESTE SETENTRIONAL BRASILEIRO: UMA PROPOSTA DE CLASSIFICAÇÃO
}

\section{GEOMORRPHOLOGY OF THE NORTHERN BRAZILIAN NORTHEAST: A CLASSIFICATION PROPOSAL}

\author{
Luis Ricardo Fernandes da Costa \\ Departamento de Geociências, Universidade Estadual de Montes Claros \\ Avenida Rui Braga, Montes Claros, Minas Gerais. CEP: 39.401-089. Brasil \\ ORCID: 0000-0001-8593-861X \\ E-mail: lricardocosta@yahoo.com.br
}

Rubson Pinheiro Maia

Departamento de Geografia, Universidade Federal do Ceará Campus do Pici, Bloco 911, Fortaleza, Ceará. CEP: 60.440-900. Brasil

ORCID: 0000-0002-1688-5187

E-mail: rubsonpinheiro@yahoo.com.br

Lucas Lopes Barreto

Departamento de Geografia, Universidade Federal do Ceará Campus do Pici, Bloco 911, Fortaleza, Ceará. CEP: 60.440-900. Brasil ORCID: 0000-0001-7569-9184 E-mail: lopes_ufc@yahoo.com.br

Vanda Carneiro de Claudino Sales

Departamento de Geografia, Universidade Estadual Vale do Acaraú Campus do Junco, Sobral, Ceará. CEP: 62.030-000. Brasil ORCID: 0000-0002-9252-0729

E-mail:vcs@ufc.br

Informações sobre o Artigo

Recebido (Received):

22/12/2018

Aceito (Accepted):

26/12/2019

Palavras-chave:

Geomorfologia; Mapeamento Geomorfológico; Nordeste Setentrional Brasileiro.

\section{Keywords:}

Geomorphology; Geomorphological mapping; Northern Brazilian Northeast.

\section{Resumo:}

No Nordeste setentrional brasileiro, as formas de relevo têm sido classicamente descritas como resultantes de sucessivos ciclos de aplainamento. Nessa perspectiva, são interpretadas como resíduos dos processos de pediplanação conduzida por climas secos. Essa ênfase morfoclimática, foi responsável por grandes avanços da geomorfologia do Quaternário através de estudos sedimentológicos associados, sobretudo aos depósitos correlativos. Nesse trabalho, pretende-se incorporar dados estruturais que subsidiem a interpretação e a classificação das formas de relevo segundo seus processos geradores. Esses processos incluem fatores estruturais ligados à tectônica e a deformação do embasamento. O trabalho tem por objetivo propor uma classificação de mapeamento geomorfológico com um enfoque multiprocessual e multiescalar para a 
referida área. A metodologia foi pautada na análise de dados geológicos, geomorfológicos e averiguações de campo, o que contribuiu para o desenvolvimento de uma taxonomia do relevo organizada em classes de Macroescala, como as Formas Denudacionais, Circudenudacionais e Agradacionais; de Mesoescala, com as Unidades Geomorfológicas; e de Microescala, com as Formas de Abrangência Espacial Restrita. Tais unidades são aqui apresentadas segundo os processos geradores responsáveis, com ênfase na estrutura, no processo e nas formas, sendo assim, uma classificação didática e que visa suprir a carência de classificações regionais de caráter genético e evolutivo para essa porção do Nordeste brasileiro.

\begin{abstract}
:
In the Northeast of Brazil, relief forms have been classically described as resulting from successive cycles of planing. From this perspective, they are considered as residues of the processes of pediplanation conducted by dry climates. This morpho-climatic emphasis was responsible for great advances in the quaternary geomorphology through sedimentological studies associated mainly with correlative deposits. In this work, it is intended to incorporate structural data to these studies, subsidizing the interpretation and classification of relief forms according to their generating processes. These processes include structural factors linked to tectonics and deformation of the basement. The objective of this work is to propose a classification of geomorphological mapping with a multiprocess and multiscale approach to the area. The methodology was based on the analysis of geological and geomorphological data and fieldwork, which contributed to the development of a relief taxonomy organized in Macro scale classes, such as Denudational, Circudenudational and Agradational Forms; of Mesoscale classes, with the Geomorphological Units; and of Microscale classes, with the Forms of Restricted Space Scope. These units, presented according to the generative process with emphasis on structure, make up a didactic classification and aim to supply the lack of regional classifications of genetic and evolutionary character related to the northern Brazilian Northeast.
\end{abstract}

\section{Introdução}

Os processos denudacionais que ocorreram ao longo do Cenozoico constituem uma das principais forças modeladoras do relevo no Nordeste Brasileiro (PEULVAST e CLAUDINO SALES, 2004; MAIA e BEZERRA, 2014). A denudação continental foi responsável pela distinção das formas de relevo, originando assim, um complexo mosaico geomorfológico que expressa em superfície, os condicionantes estruturais responsáveis pela morfologia atual da Província Borborema (MAIA e BEZERRA, 2014). Entretanto, é preciso ressaltar que essa denudação ocorreu em terrenos diferentes, com idades distintas e diferentes litologias, afetados por vários graus de deformação e metamorfismo. Assim, as formas residuais resultantes da erosão diferencial sobre estruturas deformacionais relacionadas aos diversos eventos tectônicos que ocorreram ao longo da formação da Província Borborema, constituem a expressão geomorfológica de superfície de processos associados à deformação crustal, ao metamorfismo, ao plutonismo e à neotectônica.

O presente trabalho foi desenvolvido na porção setentrional do Nordeste brasileiro, área que corresponde a
Província Borborema, situada a leste da Bacia Parnaíba e ao norte do Cráton São Francisco (ALMEIDA et al. 2000). Esta área é caracterizada por terrenos de idade Arqueana e Proterozoica, agrupando litologias metamórficas e ígneas, separados por falhas e lineamentos de direção predominante NE-SW e E-W (VAUCHES et al. 1995). Sobre este substrato Pré-Cambriano ocorrem diversas bacias sedimentares Paleozoicas e Mesozoicas, além de coberturas Cenozoicas (RADAM, 1981a), como está representado na figura 1.

As cotas altimétricas na área são variadas, com valores de 0 a 200m na faixa costeira, aumentando em setores específicos em direção ao interior, onde podem ultrapassar os $1.000 \mathrm{~m}$ no topo dos relevos mais elevados (Figura 2).

Baseando-se na interpretação voltada aos processos modeladores da superfície terrestre, em consonância com os aspectos morfoestruturais, é apresentada uma classificação geomorfológica da área em análise. O objetivo deste artigo é propor um mapeamento geomorfológico com um enfoque multiprocessual e multiescalar para essa porção do Nordeste Brasileiro, onde o modelado é produto da interação dos processos morfoestruturais e morfoclimáticos. 
Geomorfologia do Nordeste Setentrional Brasileiro: Uma Proposta de Classificação

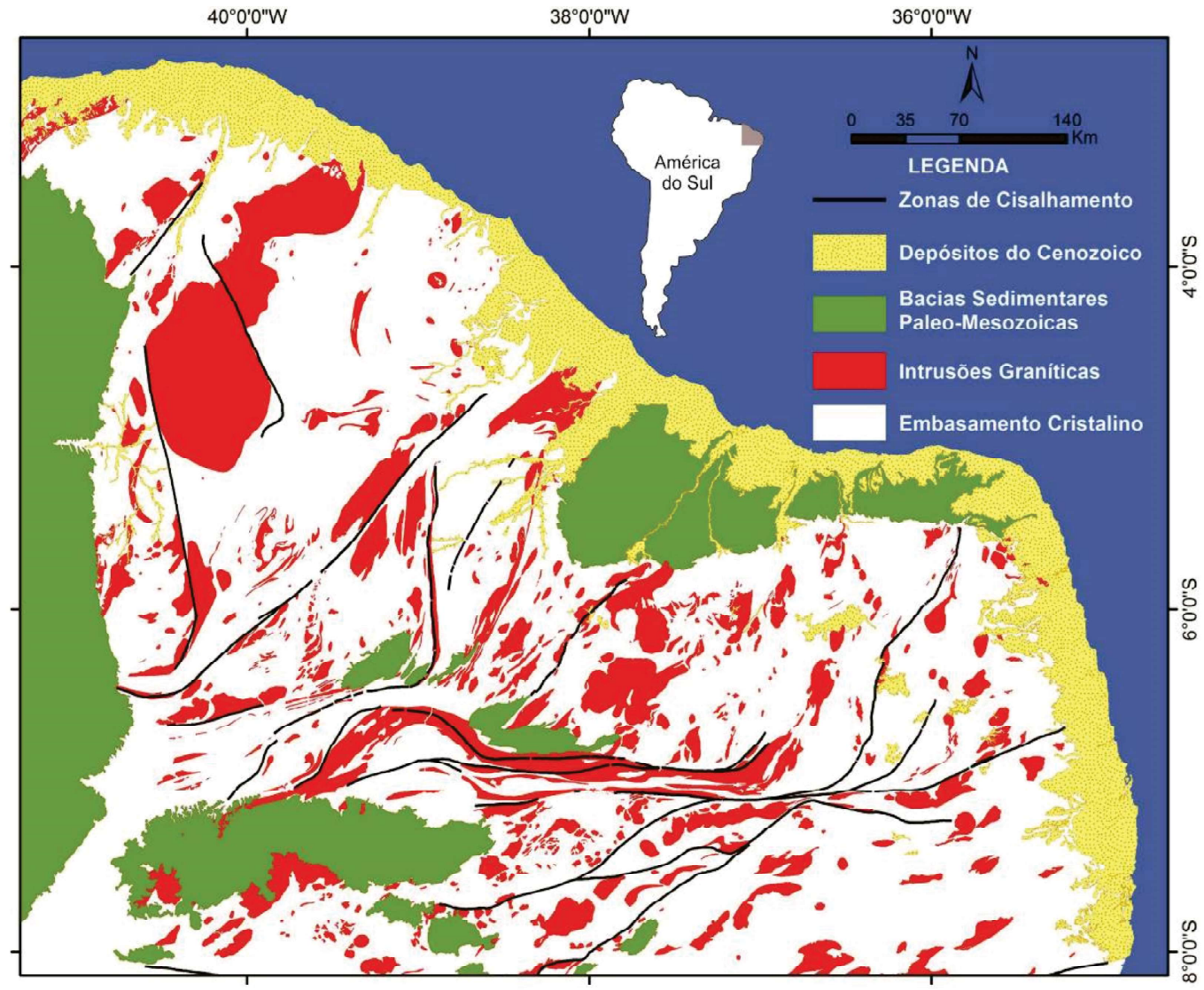

Figura 1 - Unidades Litoestruturais do Nordeste Setentrional. Fonte: Sintetizado de diversos autores e de dados de geologia do Nordeste Brasileiro - CPRM.

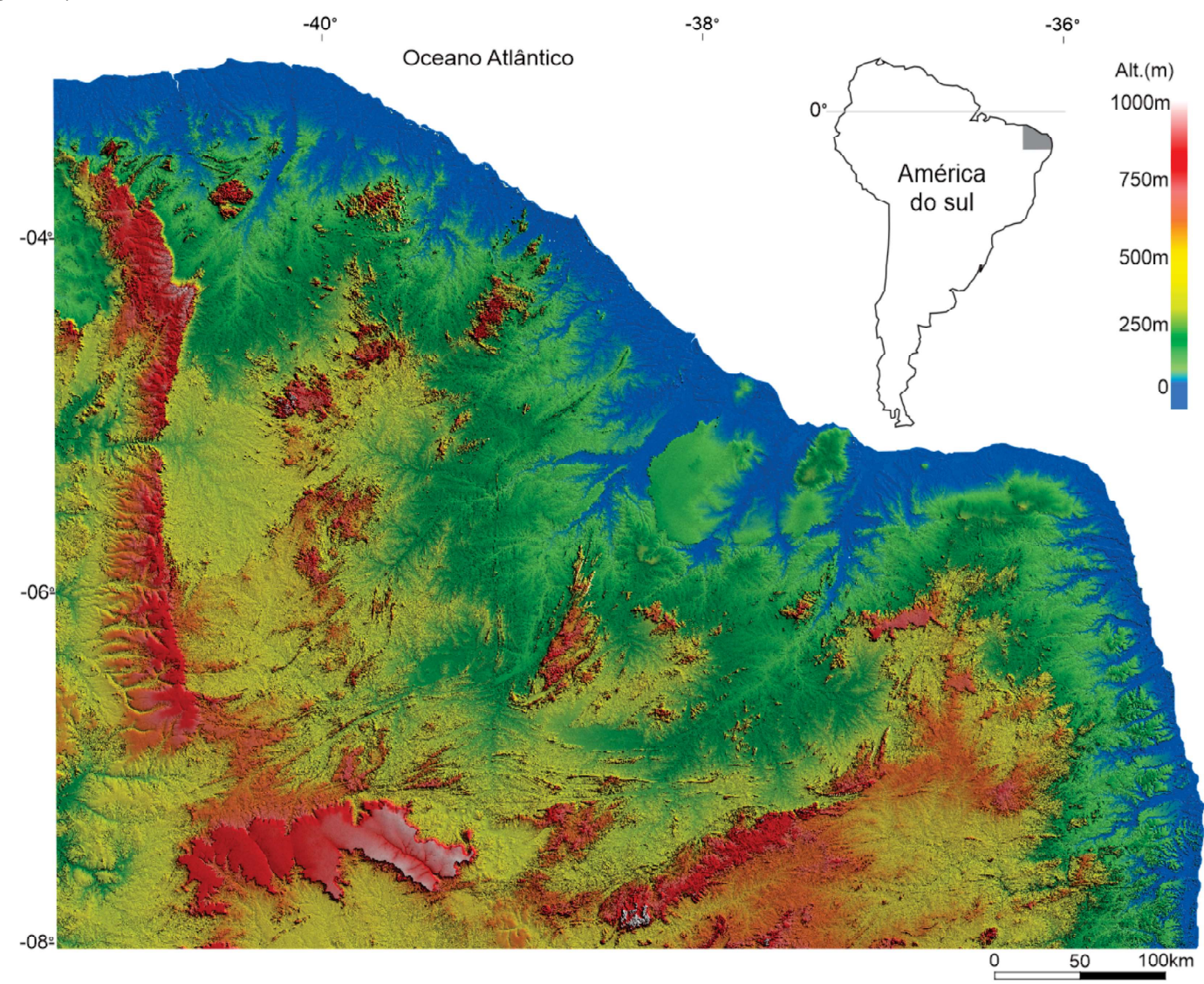

Figura 2 - Mapa de altitude do Nordeste Setentrional. Fonte: Elaborado a partir de dados SRTM 


\section{Materiais e Métodos}

As propostas metodológicas de mapeamento geomorfológico clássico são baseadas nos táxons de grandeza de Tricart (1965), em que a representação cartográfica das unidades de relevo e os processos do modelado estão atrelados a abrangência espacial da feição geomorfológica, o que pode ser apreciado nas classificações de Barbosa et al. (1984) e Ross (1992), esta última representada na figura 3.

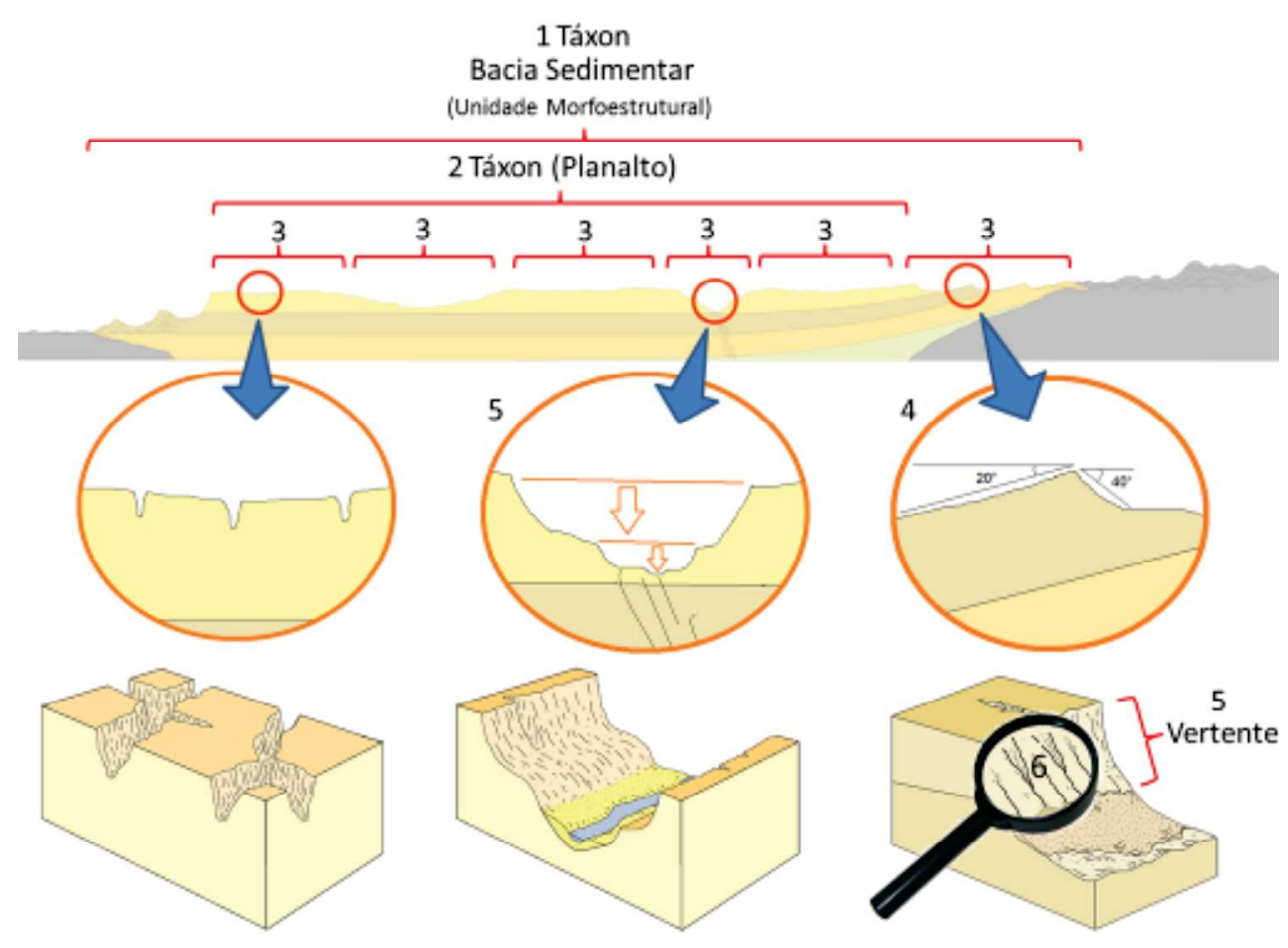

Figura 3 - Esquema demonstrativo da metodologia de compartimentação geomorfológica proposta por Ross (1992)

Com efeito, a metodologia de classificação do relevo em táxons de Ross (1992), faz uma compartimentação em unidades morfoestruturais ( $1^{\circ}$ táxon) até formas de menor escala e com influência antrópica ( $6^{\circ}$ táxon), o que acaba por fazer um engessamento metodológico, pois limitam a apreensão de ações dos processos endógenos e exógenos em determinados níveis taxonômicos.

Neste trabalho procura-se estabelecer na interpretação do relevo as características multiprocessual e multiescalar, onde os processos modeladores ocorrem de forma concomitante e com diferentes intensidades. Dessa forma, as feições geomorfológicas com limitadas extensões espaciais podem ter elevada atuação dos aspectos morfoestruturais. Isso seria inviável na metodologia clássica, já que a morfoestrutura age de modo acentuado apenas nos primeiros níveis taxonômicos, e a modelagem seria realizada nos níveis 5 e 6 por fatores externos e antrópicos.

O caráter multiescalar busca entender a evolução geomorfológica por meio dos diferentes tipos de relevo, suas interações e suas diferentes áreas de abrangência. Deste modo, a ocorrência de determinados relevos pode indicar variações climáticas, mudanças do nível de base, recuo de vertentes ou atividades neotectônicas.

A classificação aqui apresentada procura salientar como os aspectos estruturais possuem relevância, assim como os processos de denudação climática, na gênese e modelagem do relevo, demonstrando de forma inequívoca a inadequação de anulação de um conjunto de processos em relação ao outro, bem como a possibilidade efetiva de junção dos dois níveis de intervenção na análise da morfologia regional. Além disso, a proposta compõe uma classificação didática, a qual vem suprir a carência de classificações de caráter genético e evolutivo do relevo do Nordeste setentrional brasileiro.

Neste sentido, há exemplos de relevos associadas com estrutura e tectônica nas formas de abrangência espacial restrita como formas de relevo cárstico, vulcânicos e vales estruturais. Por esse motivo o mapa não 
seguiu essa compartimentação clássica do relevo. Esta baseou-se na relação estrutura/processo/forma (Figura 4), sendo entendida como toda a pré-disposição litológica à dissecação ou agradação direcional.

Nesse sentido, a compartimentação de classes de relevos e morfoestruturas no mapeamento efetuado seguiu a seguinte disposição: Unidades de Macroescala (denudacionais, circudenudacionais e agradacionais) foram representadas por polígonos, representando as maiores unidades e com uma ligação direta com a morfoestrutura.

As Unidades de Mesoescala foram representadas pelas Unidades Geomorfológicas, com uma abordagem pautada nos processos morfodinâmicos de esculturação do relevo, representadas por polígonos, e elementos complementares como escarpas e cristas, ilustradas por "linhas" devido a variada dimensão espacial.

Por último as Unidades de Microescala, representadas pelas Formas de Abrangência Espacial Restrita (FAER), as quais, devido a escala adotada, foram ilustradas de forma pontual, tal é o caso de boqueirões, cânions, carste, relevos vulcânicos, domos e colinas. Para a delimitação destas unidades utilizou-se da análise dos dados geológicos, além do uso da análise geomorfológica. Dessa forma foi possível definir 129 unidades de abrangência espacial restrita.

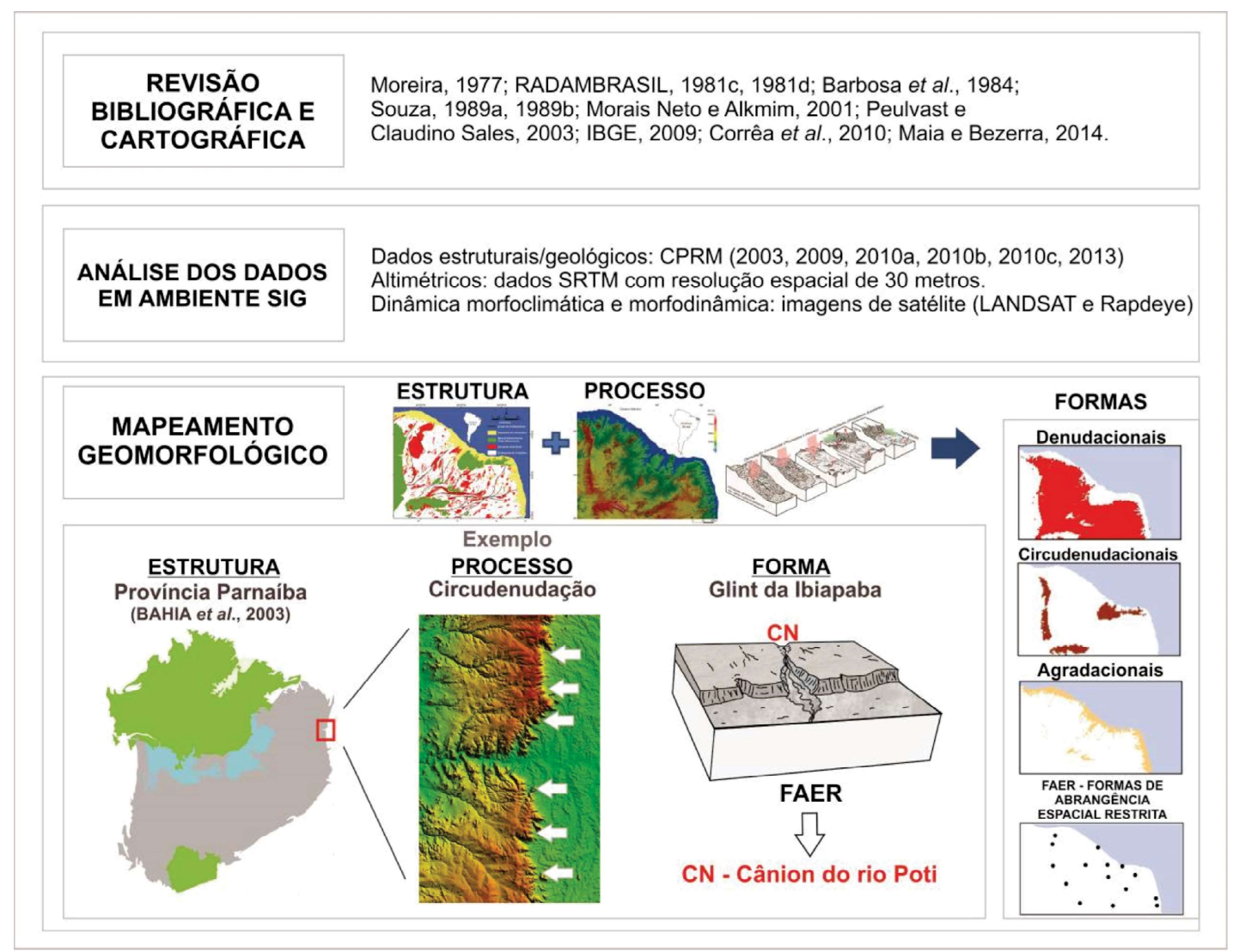

Figura 4 - Esquema representativo da metodologia da compartimentação geomorfológica baseada na relação estrutura/processo/forma

Os boqueirões e cânions foram delimitados pela intensidade de dissecação dos rios sobre os materiais geológicos. Nesse sentido, quando a dissecação atinge as cristas residuais formam-se os boqueirões, enquanto que nos cânions, a erosão fluvial é intensa dissecando diferentes estruturas e formas sobrejacentes. A diferença está no grau de encaixamento: os cânions têm paredes praticamente verticais, e os boqueirões possuem vales mais abertos e dissecam até alcançar o nível da superfície sertaneja.

Os relevos cársticos e vulcânicos foram pontuados baseados na ocorrência de materiais geológicos típicos destas feições, além das formas derivadas e com suas devidas expressividades para as unidades geomorfológicas. Para a espacialização do carste foi utilizada da base do Cadastro Nacional de Informações Espeleológicas (CANIE). Os domos e colinas foram definidos segundo suas formas e extensão. 
Para a elucidação escalar do trabalho, foram realizados vários mapeamentos intermediários e complementares nas escalas de 1:50.000, 1:100.000 e $1: 250.000$, para que de fato todos os três níveis adotados fossem contemplados e passíveis de organização em ambiente SIG e averiguação no campo. Entretanto, o mapa síntese do artigo, devido a abrangência da área, foi organizado na escala de 1:950.000, com todas as informações e legendas adequadas para sua visualização.

Por fim, para melhor representar espacialmente a dinâmica do modelado, foi utilizada da metodologia de representação do IBGE (2009), onde os diferentes níveis de classificação do relevo estão dispostos na forma de blocos diagramas.

O produto final foi gerado a partir das seguintes etapas: revisão de literatura, aquisição e construção do SIG, averiguação nos trabalhos de campo e mapeamento geomorfológico. Na primeira etapa foram realizadas as revisões bibliográfica e cartográfica da geomorfologia do Nordeste brasileiro, que buscou entender as principais linhas de intepretações de evolução e mapeamento do relevo regional (MOREIRA, 1977; RADAMBRASIL, 1981a, 1981b; BARBOSA et al. 1984; SOUZA, 1989a, 1989b; SOUZA et al. 1992; MORAIS NETO e ALKMIM, 2001; PEULVAST e CLAUDINO-SALES, 2003; IBGE, 2009; CORREIA et al. 2010; MAIA e BEZERRA, 2014).

$\mathrm{Na}$ segunda etapa foi realizado a aquisição dos dados cartográficos dos dados vetoriais dos aspectos geológicos e geomorfológicos (CPRM, 2003, 2009, 2010a, 2010b, 2010c, 2013), e dos dados rasters do Shuttle Radar Topography Mission (SRTM) da National Aeronautics and Space Administration (NASA) e LANDSAT 8, ambos materiais com 30 metros de resolução espacial (USGS, 2015).

$\mathrm{Na}$ terceira etapa foi realizado o Mapeamento, onde se delimitou as estruturas, sendo viável pelos dados geológicos vetoriais; e os processos, por meio dos rasters $e$ averiguação nos trabalhos de campo, que possibilitaram compreender a forma e processos morfoclimáticos atuantes. Nessa relação entre estrutura e processo, somados com a revisão de literatura, gerou as formas denudacionais, circudenudacionais, agradacionais e as formas de abrangência espacial restrita.

Essas etapas foram importantes para a elucidação dos processos de esculturação e classificação das unida- des, sendo essa pautada nos processos morfoestruturais, morfoesculturais e morfodinâmicos, oriundos da análise bibliográfica e de resultados de trabalhos de campo realizados na área de estudo ao longo da última década.

Todos esses dados foram analisados em ambiente SIG, o que possibilitou a correlação das informações com uso do software ArcGis 10.1 (licença disponível no Programa de Pós-Graduação em Geografia da Universidade Federal do Ceará), além do uso de software, CorelDRAW, para a produção dos blocos diagramas.

\section{Resultados}

A relação entre estruturas, processos de denudação e relevo é evidenciada pela erosão diferencial, o que resulta no alinhamento de cristas residuais, vales estruturais e escarpas de falha, associadas às faixas móveis Pré-Cambrianas e seus trends estruturais reativados no Cretáceo e no Cenozoico (MAIA e BEZERRA, 2014).

Essas reativações têm influenciado a geometria de formas erosivas e agradacionais gerando relevos estruturais orientados segundo as direções E-W e NE-SW. São exemplos dessas formas (Figura 5) as bordas de bacias, os maciços cristalinos, vales estruturais, planícies aluviais, e em escala de detalhe, as formas cársticas.

Os processos erosivos areolares e lineares contribuíram dessa forma para a estruturação das formas de relevo atual, com a formação de diferentes unidades geomorfológicas. Componentes como o arranjo estrutural, em conjunto com fatores como a existência de diferentes litologias em decorrência de plútons graníticos e capeamentos lateríticos favoreceram a formação de campos de inselbergs e platôs lateríticos, além de atestar processos de inversão de relevo.

As cristas residuais, alinhadas segundo as direções tectônicas principais, bordas de planaltos sedimentares afetados por soerguimento e modelados pela erosão diferencial, maciços residuais individualizados por superfícies aplainadas onde os processos erosivos suplantaram os agradacionais e as planícies costeiras modeladas pela eustasia, compõem o complexo mosaico paisagístico nordestino que documenta importantes episódios de sua evolução morfotectônica e paleoclimática. Dentre essas unidades, a planície litorânea, os vales fluviais e os tabuleiros costeiros evidenciam importantes indicadores de eventos neotectônicos (MAIA e BEZERRA, 2014). 


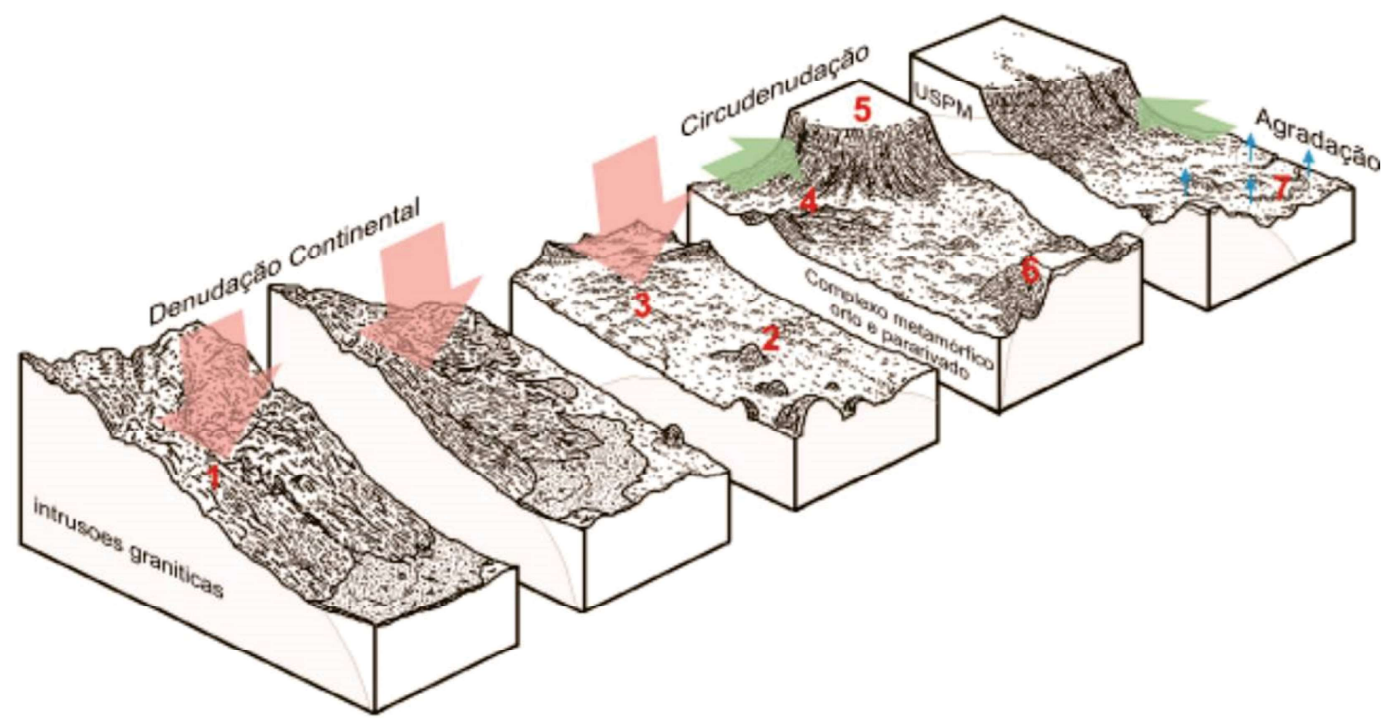

Figura 5 - Unidades do Relevo do Nordeste setentrional brasileiro - 1: Maciços cristalinos, 2: Campos de inselbergues, 3: Superficie Sertaneja, 4: Cristas residuais, 5: Planaltos e Cuestas, 6: Pequenos platôs em maciços, 7: Planícies (fluviais e litorânea) e Tabuleiros. (USPM: Unidades sedimentares paleo-mesozoicas).

\subsection{Formas Denudacionais}

São relevos que reiteram ação da erosão diferencial sobre os materiais geológicos de diferentes composições e idades. Essa unidade se destaca não apenas pela diversidade das formas, mas principalmente em sua larga extensão, que evidencia o papel dos processos denudacionais na evolução das formas do relevo.

\subsubsection{Superfície Sertaneja 1, Superfície Sertaneja 2 e Superfície Pré-litorânea}

As superfícies de aplainamento, maior unidade reconhecida no mapa proposto, é representada por três níveis topográficos distintos. Utilizando-se de critérios altimétricos, de dissecação e de localização, foi possível estabelecer as características de cada unidade, com destaque para a morfologia associada a cada compartimento de relevo. Dessa forma, foram divididas em Superfície Sertaneja 1 (SS1), Superfície Sertaneja 2 (SS2) e Superfície Pré-litorânea (SPL). O termo depressão sertaneja, largamente utilizado na literatura clássica, é compreendido aqui como insuficiente para a compreensão dos processos de aplainamento e esculturação dessas superfícies (PEULVAST e CLAUDINO SALES, 2002).

A SS1 é típica de áreas mais baixas, constituindo-se como as áreas onde os processos de aplainamento são mais evidentes. Do ponto de vista altimétrico, está localizada entre cotas de 50 e $250 \mathrm{~m}$ aproximadamente, com topografias planas ou levemente onduladas.

A SS2, com níveis altimétricos superiores a 250 $\mathrm{m}$, alcança aproximadamente a cota de $400 \mathrm{~m}$, na base dos maciços residuais. Geralmente, nessa cota há uma morfologia mais dissecada, com a formação de interflúvios mais destacados e colinosos (SOUZA, 1988) e situa-se mais no interior do continente (provavelmente em função da ação da flexura marginal), como se pode notar na figura 6 .

Além da diferenciação dessas duas tipologias de Superfície Sertaneja, ainda é possível distinguir um terceiro padrão, a Superfície Pré-litorânea (SPL), que abrange toda a porção oriental, embutida entre o maciço da Borborema e os tabuleiros costeiros, com formas modeladas em climas mais úmidos (MOREIRA, 1977; CORRÊA et al. 2010). Ao norte, a SPL tem contato com os rebordos e patamares e a NO com a SS1, na bacia do Rio Piranhas-Açu, quando delimita-se junto a bacia do Rio Ceará-mirim.

A complexidade litológica associada às superfícies aplainadas dificulta sua caracterização geológica. Neste caso, o metamorfismo associado a essas zonas condiciona os processos de erosão diferencial entre as superfícies aplainadas e os maciços cristalinos. 


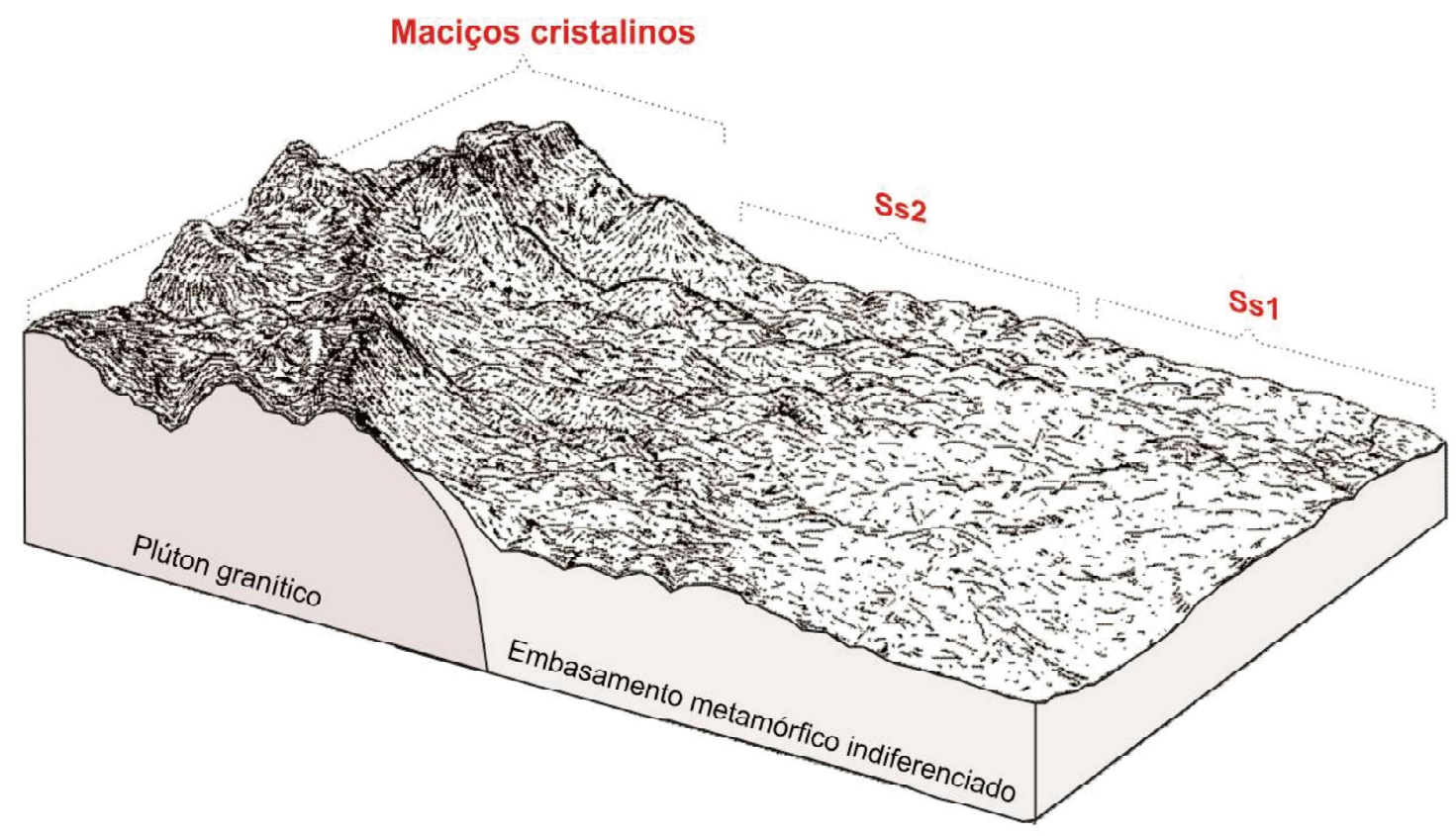

Figura 6 - Diferentes niveis de dissecação na superficie sertaneja

Os processos de dissecação são comandados, sobretudo, pelas correntes fluviais que seguem as direções tectônicas marcadas por estruturas rúpteis e dúcteis do embasamento (MAIA e BEZERRA, 2014). As porções mais resistentes à erosão, normalmente associadas geologicamente a núcleos graníticos exumados, permanecem como sobressaltos topográficos que se distinguem da topografia aplainada da superfície sertaneja. Essas elevações residuais são denominadas inselbergues quando afloram isoladamente e inselgebirgues quando se dispõem em conjunto (PEULVAST et al. 2006).

As elevadas taxas de erosão desencadeadas sobretudo pelo contexto climático semiárido, limitam a pedogênese, tornando os solos da superfície sertaneja rasos. Nesse contexto, comumente, a rocha matriz (embasamento) aflora. Conforme Bigarella (2003) as elevadas taxas de erosão decorrem do contexto de variabilidade climática onde alternaram-se fazer úmidas e secas.

Nas fases úmidas, com o predomínio da pedogênese sobre a morfogênese, espessos regolitos se originavam sendo os processos erosivos limitados aos vales fluviais. Nos casos de predomínio da morfogênese sobre a pedogênese intensos processos erosivos remobilizaram os mantos de alteração situados nas escarpas para os fundos de vale.

Os processos erosivos associados ao regime climático favorecem a remoção das fáceis mais finas dei- xando apenas os blocos parcialmente intemperizados do saprólito. Essa remoção ocorre a partir do escoamento superficial difuso e sua capacidade de remoção de sedimentos é diretamente proporcional ao volume escoado.

Esses processos erosivos são principalmente associados ao clima semiárido onde os longos períodos de estiagem expõem o manto de alteração a erosão que ocorre principalmente pelo regime de chuvas esporádico e catastrófico (elevados índices pluviométricos em curto espaço de tempo). A exumação do embasamento diaclasado expõe os blocos parcialmente meteorizados que passam a caracterizar a paisagem sertaneja.

\subsubsection{Maciços cristalinos}

Em geral os granitos orogênicos são interpretados como resultado da intrusão em regiões extensionais associadas as estruturas tectônicas locais e regionais (NEVES, 2012). Na Província Borborema essas estruturas são representadas principalmente por zonas de cisalhamento de direção NE-SW e E-W (VAUCHES et al. 1995). As zonas de cisalhamento são condutos por onde pode circular um grande volume de fluidos (TRINDADE et al. 2008). A grande maioria dos corpos graníticos observados nos mapas geológicos, está associada às zonas de cisalhamento (ALMEIDA e ULBRICH, 2003). 


\section{Geomorfologia do Nordeste Setentrional Brasileiro: Uma Proposta de Classificação}

São áreas onde há a maior ocorrência dos corpos maciços que compõem as cotas mais elevadas no Nordeste. Os maciços cristalinos, dessa forma, são elementos importantes na interpretação do relevo regional, seja na perspectiva dos estudos dos processos erosivos, ou na temática da tectônica, esta última principalmente no que se refere a separação da Pangea, e do vulcanismo Cenozoico.

Os maciços cristalinos são relevos de características montanhosas, na maioria das vezes isoladas, e com dissecação acentuada, provocada por ações intempéricas/erosivas pretéritas e atuais. A ação da erosão diferencial tem destaque, sendo condicionada pelos lineamentos, com a formação de vertentes, escarpas e desníveis topográficos.

Como cada maciço possui particularidades, foram individualizados em seis grandes subunidades: Maciços do Ceará Central, Maciços do Alto Jaguaribe, Maciço do Pereiro, Maciço de Baturité, Maciço de Uruburetama, Maciço da Meruoca, além de outras elevações mapeadas como maciços cristalinos. O Maciço da Borborema, em decorrência da magnitude e sua importância no contexto do Nordeste Setentrional foi descrito e analisado em seção a parte.

Os Maciços do Ceará Central têm um alinhamento preferencial no sentido SSO-NNE. São formados por um conjunto de relevos residuais elevados, com níveis altimétricos em torno de $600 \mathrm{~m}$, com litologias do Pré-Cambriano (SOUZA, 1988). Nesse sentido destacam-se a Serra das Matas e a Serra da Pedra Branca, com relevos com formas que variam entre cristas e colinas. Por vezes os topos apresentam uma topografia plana, resultado principalmente da pouca efetivação dos processos lineares, em decorrência das condições hidroclimatológicas serem homólogas ao semiárido.

Os Maciços do Alto Jaguaribe são compostos por materiais cristalinos do Pré-Cambriano dos Subdomínios do Ceará Central e Jaguaribeano, sendo um conjunto de serras de altimetria inferior a 600 metros, com topos convexos e aguçados distribuídos de modo isolado na região do alto curso do rio Jaguaribe. A área apresenta uma forte influência da tectônica, demostrada pelos dobramentos, falhamentos, paralelismos e alinhamentos das cristas retilíneas e/ou semicirculares (RADAMBRASIL, 1981a; SOUZA, 1988).

As elevações cristalinas que compõe esta unidade são as serras do Tataira/Dentro e do Quincuncá, com orientação das vertentes $\mathrm{SW}$ - NE, sofrendo influência das Zonas de Cisalhamento de Senador Pompeu e Orós; e Serra do Furtado/Santa Maria cuja as orientações SW - NE e E -W, mostrando influência também da Zona de Cisalhamento de Patos.

O Maciço do Pereiro é composto de rochas cristalinas do Suíte Doutor Severiano e Suíte São Miguel, com formas convexas e aguçadas. A altimetria varia entre 500 a $900 \mathrm{~m}$, com orientação das vertentes SW - NE (RADAMBRASIL, 1981a), com limite entre as Zonas de Cisalhamento Jaguaribe e Porto Alegre. Estas últimas por sua vez, atuam na estruturação do Maciço do Pereiro, questionando a própria natureza residual, a evidenciar aspectos que mostram fatores de influência tectônica na área como a ocorrência de bacias Cretáceas e Quaternárias sobre o maciço (GURGEL et al. 2013).

O Maciço de Baturité, além dos pequenos Maciços de Maranguape, Juá-Conceição e Aratanha, se destacam pela sua proximidade da região litorânea, sendo elevações cristalinas mais próximas do litoral do Nordeste Setentrional. São constituídas por quartzitos, paragnaisses, metacalcários, micaxistos e granitóides das Unidades Independência e Canindé do Complexo Ceará, de idade Paleoprotezóica (CPRM, 2003). A composição das escarpas, cristas e cimeiras acaba por influenciar na não efetivação da erosão regressiva, sustentando áreas mais elevadas (BÉTARD e PEULVAST, 2011; BASTOS, 2012).

O Maciço de Baturité possui a orientação NNE SSW, com altimetria variando entre 500 a $800 \mathrm{~m}$, com topos convexos, lombadas e cristas, possuindo vales em $\mathrm{V}$ e planícies alveolares na porção mais úmida (SOUZA, 1988).

O Maciço de Uruburetama é composto por granitóides da Suíte Tamboril - Santa Quitéria do Paleoprotezóico (CPRM, 2003). Possui altitudes com média de $850 \mathrm{~m}$, com relevo montanhoso, com formação de cristas e colinas.

O Maciço da Meruoca é formado por Monzonitos, granodioritos e sienitos da Suíte intrusiva subalcalina a alcalina Meruoca do Paleozoico (CPRM, 2003). Sua extensão é limitada com formato em losango devido as falhas e Zonas de Cisalhamentos que estão na área periférica, com forte influência do Lineamento Transbrasiliano.

Segundo Claudino-Sales e Peulvast (2007), o Lineamento Transbrasliliano foi reativado no Cretáceo 
e após processos erosivos contribuiu na esculturação do Maciço da Meruoca e dos inselbergs de Chaval, no Ceará. A orientação do Maciço da Meruoca é predominantemente $\mathrm{SW}-\mathrm{NE}$, com cotas máximas variando de 500 metros até $1000 \mathrm{~m}$, com topos aguçados e convexos (SOUZA, 1988; RADAMBRASIL, 1981b). No setor norte possui maior umidade, com ocorrência de vales em V e planícies alveolares. No setor sul, há ocorrência de compartimento menor, denominado de Serra do Rosário, onde as condições hidroclimatológicas são equiparadas a superfície sertaneja (SOUZA, 1988).

\subsubsection{Maciço da Borborema}

A leste da Província Borborema, encontra-se o Maciço da Borborema, expressão maior da porção oriental do NE setentrional, com uma vasta extensão e com morfologias associadas a diversas litologias e condições climáticas adversas.

O relevo do Maciço da Borborema corresponde ao conjunto de terras altas que se distribuem ao longo da fachada do Nordeste oriental do Brasil, ao norte do rio São Francisco, acima da cota 200 m, cujos limites são marcados por uma série de desnivelamentos topográficos, sendo sua gênese epirogênica associada à fragmentação da Pangea e ao magmatismo intraplaca atuante ao longo do Cenozoico (PEULVAST e CLAUDINO-SALES, 2004; CORREA et al. 2010), o qual teria produzido arqueamento/bombeamento desse segmento do território nordestino, o que explicaria a macicez e topografia elevada do conjunto geomorfológico.

Com escarpas ligeiramente paralelas à linha de costa, os relevos apresentam aspectos distintos em relação as condições climáticas (MOREIRA, 1977). Na porção ocidental, as condições semiáridas impõem morfologias típicas da superfície sertaneja, com cristas residuais e inselbergs, diferente das escarpas da borda oriental, com níveis de dissecação mais evidentes em decorrência da ação erosiva fluvial incisiva resultante de maior umidade, dado a maior proximidade com o litoral.

Lima (2008) observou que o intemperismo na área do maciço da Borborema no período de 16 a 7 Ma foi caracterizado pelo enriquecimento de óxidos/hidróxidos de manganês e ferro, o que sugere que essa região estava sob um clima quente e úmido (LIMA, 2008).

\subsubsection{Pequenos platôs em maciços}

Os pequenos platôs em maciços (Figura 7) são, de forma geral, sustentados por duricrostas lateríticas, e localizam-se principalmente no sul do estado do Ceará e dispersos no Rio Grande do Norte e Paraíba, em cotas que variam de 600 a $700 \mathrm{~m}$.

Os platôs situados na porção oriental incluem os Maciços de Portalegre, Martins, João do Vale, sustentados por arenitos da Formação Serra do Martins, e os demais, dispersos sobre o Maciço da Borborema, em muitos locais com a porção superficial em avançado estágio de laterização (MORAES NETO e ALKMIM, 2001; MAIA et al. 2016).

No sul do Ceará, os platôs são constituídos pelas coberturas colúvio-eluviais detríticas, com ocorrência de áreas laterizadas (BÉTARD et al. 2005; PEULVAST e BÉTARD, 2015). Esses platôs ainda podem indicar processos de inversão do relevo, desencadeados por processos de soerguimento regional e posterior erosão diferencial, observados na região sul do Ceará (PEULVAST e BÉTARD, 2015) e nos Maciços de Portalegre e Martins (MAIA et al. 2016).

\subsection{Formas Circudenudacionais}

As formas circudenudacionais referem-se aos relevos desenvolvidos nas bordas das bacias sedimentares que atualmente compõem os planaltos do Nordeste Brasileiro. Em geral seu alçamento topográfico deve-se a processos tectônicos de soerguimento e a erosão diferencial.

\subsubsection{Chapada cuestiforme do Apodi, superfície Jandaíra e rebordos e patamares}

A Chapada cuestiforme do Apodi compreende um baixo planalto situado entre 100-140 m sobre os terrenos Cretáceos da Bacia Potiguar. Encontra-se geneticamente relacionada a uma série de bacias interiores de idade Cretácea, que compõem o Sistema de riftes do Nordeste Brasileiro (MATOS, 2000). Seu arcabouço estrutural é constituído por um conjunto de grábens assimétricos de direção NE-SW separados por horst do embasamento. Esta construção estrutural denominada de Rifte Potiguar originou-se a partir da reativação das estruturas dúcteis do embasamento cristalino durante o Cretáceo Inferior que formam o trend NE-SW (NÓBREGA et al. 2005; DE CASTRO et al. 2012) a partir da separação Brasil-África. 


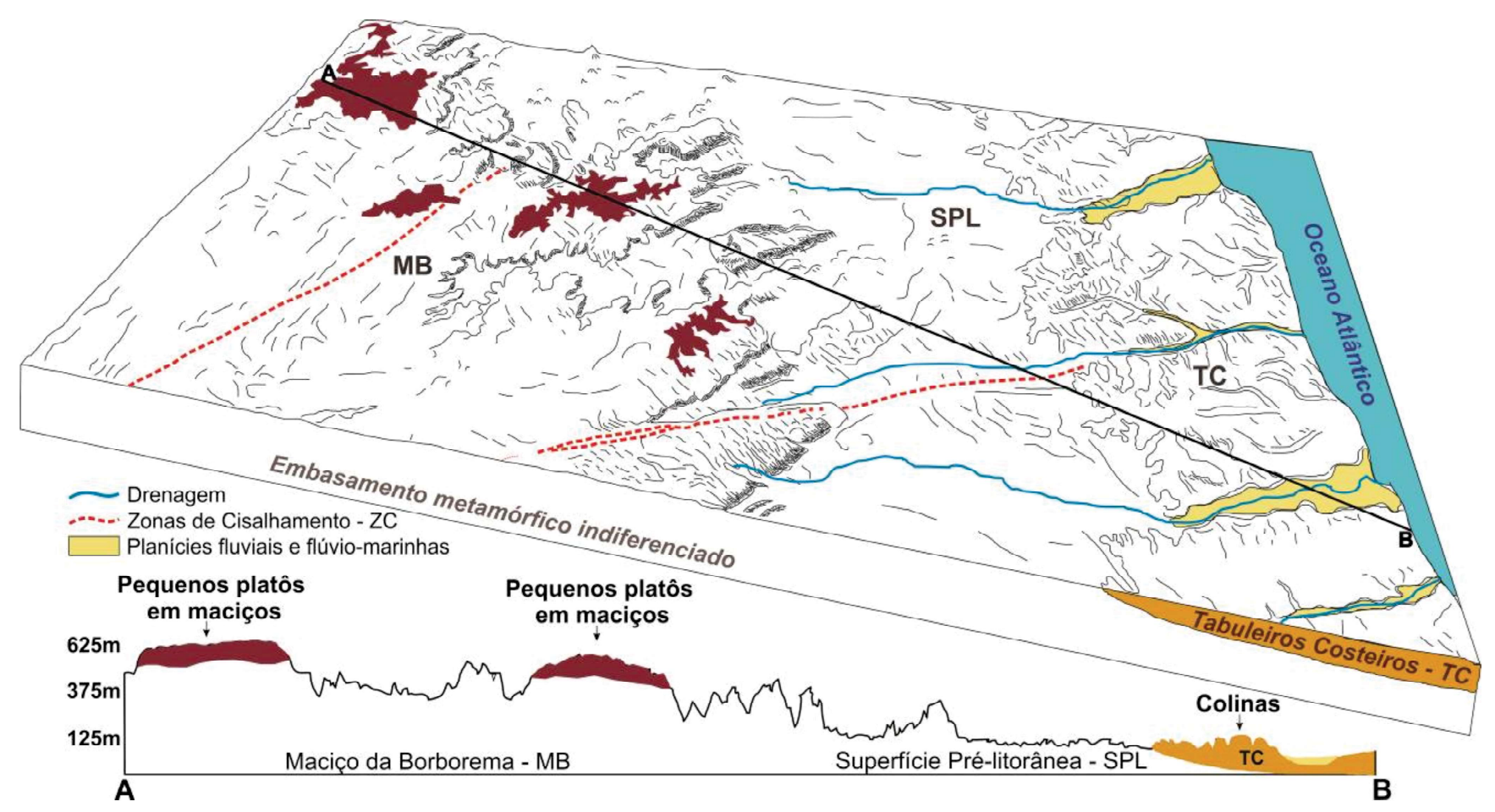

Figura 7 - Perfil E-W representando diferentes unidades geomorfológicas. Perceber a ocorrência dos Pequenos platôs em maciços no Maciço da Borborema

A porção emersa da Bacia Potiguar constitui uma cuesta que se estende pelo segmento oeste do estado do Rio Grande do Norte e o extremo leste do estado do Ceará, com front voltado para S e SW e reverso para NE e com inclinação de $0,1^{\circ}$. No front, a cornija íngreme é sustentada por rochas carbonáticas da Formação Jandaíra, com somital de aproximadamente $140 \mathrm{~m}$ (MAIA e BEZERRA, 2014).

A bacia e a chapada, situada na porção oeste, no estado do Rio Grande do Norte, alonga-se como uma superfície predominantemente plana, sustentada pelo calcário Jandaíra. Constituindo-se como unidade geomorfológica, resguarda em sua topografia as características associadas com deposição e acamamento.

Na base, o front forma uma rampa com inclinação muito variável moldada nos arenitos da Formação Açu, formando os rebordos e patamares. Esse setor apresenta dissecação incipiente realizada por canais de $1^{\circ}$ e $2^{\circ}$ ordem dos tipos anaclinais e ortoclinais em direção à superfície sertaneja que limita a área do embasamento Pré-Cambriano, no contato com a bacia sedimentar.

\subsubsection{Planalto do Araripe, depressão periférica e baixos platôs da Formação Mauriti}

A área de ocorrência da Chapada do Araripe é caracterizada pela presença de um relevo variado nos seus arredores, com formas tabulares do tipo chapadas e glints, além de feições cuestiformes e morros testemunhos (PEULVAST; BÉTARD, 2016), razão pela qual a denominamos aqui de "Planalto do Araripe". O Planalto do Araripe apresenta cotas altimétricas que chegam a $900 \mathrm{~m}$ e bordas escarpadas. Por vezes é bordejada pelo escudo cristalino subsequente ou pacotes sedimentares da bacia homônima. Os arenitos da Formação Exu funcionam como unidade que mantém as feições planas, com níveis de dissecação incipientes (SOUZA, 1988). A topografia plana e monótona da chapada só é interrompida por vales localizados principalmente a sul e sudeste.

Atualmente dois modelos de evolução geomorfológica propõem explicar o relevo da bacia. Marques et al. (2014) associam a origem do planalto ao soerguimento da bacia no Cretáceo, enquanto Peulvast e Bétard (2015) associam o relevo elevado à erosão diferencial.

As escarpas íngremes, observadas na área, são testemunho da erosão diferencial, marcadas pelo recuo das vertentes (backwearing), ocasionando o que Peulvast e Bétard (2015) denominam de inversão topográfica, intensificados por mecanismos como os movimentos de massa.

A NE do Planalto do Araripe, forma-se uma ampla depressão periférica, tendo como litologia pre- 
ponderante os arenitos das Formações Mauriti, Brejo Santo, Missão Velha e Rio Batateiras (CPRM, 2003). Trata-se de uma vasta área aplainada, bem delimitada e com cotas inferiores a superfície sertaneja subsequente. Apresenta, por vezes, morros testemunhos, intercalados por proeminência de feições com topos dissecados em cristas ou colinas.

Ao sul do Planalto do Araripe, em Pernambuco, os arenitos da Formação Mauriti sustentam baixos platôs sedimentares, em contraposição ao seu comportamento morfológico a NE da Chapada do Araripe, destacando-se como ressaltos topográficos em meio aos níveis da superfície sertaneja 2 .

\subsubsection{Glint da Ibiapaba}

Na porção oeste do Ceará limitando-se com o estado do Piauí, desenvolve-se o escarpamento na borda E da Bacia do Parnaíba. Trata-se de um relevo na forma de glint, com parte da vertente e sopé mantidos por rochas cristalinas (SOUZA, 1989a; CLAUDINO-SALES, 2002; CLAUDINO-SALES e LIRA, 2010; BARRETO e COSTA, 2014; MOURA-FÉ, 2015), estrutura cuestiforme e front voltado para leste e o reverso para oeste. Tal relevo é sustentado pelos arenitos do Grupo Serra Grande, pertencente a Província Parnaíba.

A Província Parnaíba configura-se como um pacote sedimentar do tipo intracratônico (BAHIA et al. 2003), apresentando inclinações suaves para o centro da bacia, com camadas mais recentes no centro e as mais antigas estendendo-se nas bordas. Segundo Neves (1999) a origem da Província Parnaíba está associada à fissão do megacontinente Panotia.

Segundo Claudino-Sales (2002), em resposta a divisão América do Sul - África, os ombros do riftes (oeste - atual região do Ceará e leste - atual região do maciço da Borborema) foram soerguidos, e com eles, no segmento cearense, solidariamente, o Grupo Serra Grande. Durante o Cenozoico, condições climáticas semiáridas resultaram na erosão do ombro soerguido (escudo cristalino adjacente), formado por rochas fraturadas menos resistentes, deixando exposto o Grupo Serra Grande (CLAUDINO-SALES, 2002).

Assim, a atuação do longo e intenso processo erosivo produziu verdadeira área de inversão topográfica, isto é, de inversão de relevo nesse segmento do território cearense (AB'SABER, 1969a; BARRETO e COSTA, 2014).

$\mathrm{Na}$ escarpa da Ibiapaba, os processos erosivos ocorrem segundo a resistência litológica do embasamento cristalino e dos arenitos do Grupo Serra Grande. Da base até setores intermediários da escarpa, entre as cotas 200 até $700 \mathrm{~m}$, a litologia é cristalina e a erosão ocorre pelo recuo de borda. No topo, entre as cotas 700 e 900m, a erosão ocorre pelo colapso de blocos de arenitos do Grupo Serra Grande. Nessa parte observa-se a ausência de dissecação na cornija que se apresenta de forma continua e, portanto, sem sulcos erosivos pronunciados que justifiquem uma dissecação do tipo fluvial. De modo distinto, na parte cristalina da escarpa observa-se elevada dissecação, com talvegues que se aprofundam a medida que se aproxima-se da cornija. Nessa, o colapso de blocos, sobretudo das fácies mais basais do arenito, resulta da erosão remontante do embasamento sotoposto. Essa erosão diferencial leva o colapso da base do Grupo Serra Grande, zona de contato com o embasamento, originando assim uma reentrância com feição semelhante a degraus invertidos. (Figura 8. Foto B).

\subsection{Formas Agradacionais}

São feições constituídas pela acumulação de sedimentos, cujo desenvolvimento vincula-se aos processos erosivos que modelaram o interior do continente, acumulando-se em setores rebaixados. Espelham as ações morfotectônicas e morfoestruturais ocorridas no Mesozoico e Cenozoico, com feições resultantes em: zona costeira, bacias sedimentares Cretáceas interiores dos rios do Peixe, Icó e Iguatu e Malhada Vermelha, e baixos cursos das bacias hidrográficas, produzindo formas com gênese relativamente recente.

Dessa forma, unidades com idades distintas como as bacias sedimentares interiores e a planície litorânea estão associadas no mesmo grupo de formas em decorrência do fator topográfico e agradacional. Assim, mesmo a maioria das unidades agradacionais com gênese associada ao Cenozoico, as unidades mais antigas por apresentarem-se como planas e rebaixadas e, portanto, análogas fisionomicamente, compõem a mesma categoria, do tipo diacrônica. 

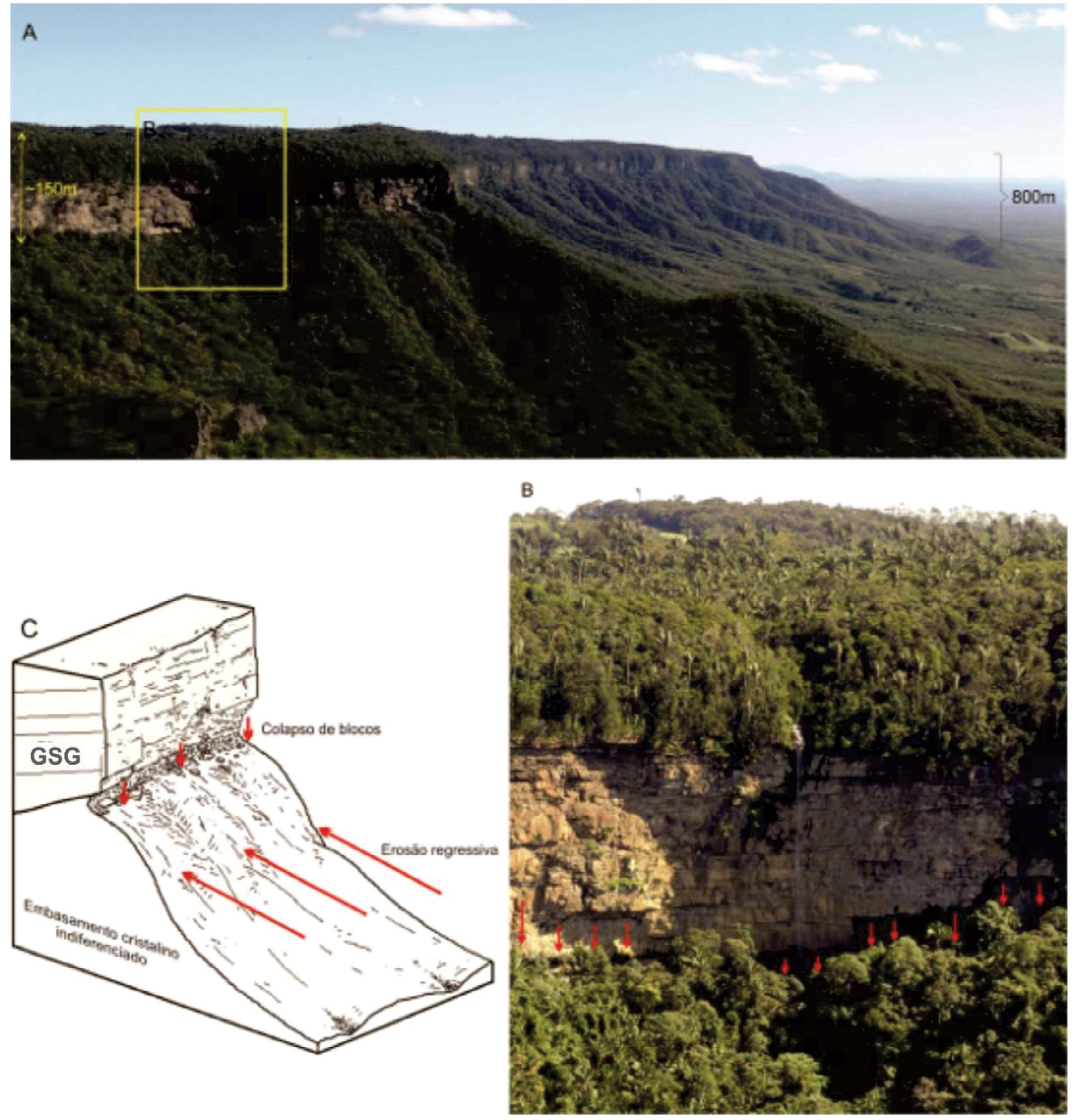

Figura 8 - Glint da Ibiapaba

\subsubsection{Planície Litorânea}

Esta unidade sintetiza a ação dos processos de ordem climática, oceanográfica, tectônica e morfosedimen$\operatorname{tar}$ (MOREIRA, 1977; CLAUDINO SALES, 2007, 2016; VITAL et al. 2006; MORAIS et al. 2006; MEIRELES, 2014; RIOS et al. 2016). Processos como a Flexura Marginal e as mudanças do nível do mar, além da dinâmica atual, são essenciais para a compreensão desta unidade.
A flexura marginal está vinculada com a instalação do Oceano Atlântico Equatorial, o que resultou na diferença de peso entre materiais litológicos continentais e oceânicos, provocando o rebaixamento do litoral e elevação do continente (CLAUDINO-SALES, 2007), contribuindo para a intensificação dos processos erosivos no interior $\mathrm{e}$, consequentemente, agradacionais na zona costeira. A zona costeira apresenta também evidências de controle 
estrutural associado com a evolução Cretácea da margem continental nordestina (CLAUDINO-SALES, 2016).

Do ponto de vista geomorfológico, esta unidade possui uma diversidade de formas como: enseadas, dunas móveis, dunas fixas, paleodunas, promontórios, flechas litorâneas, planícies flúviomarinhas, planícies flúvio-lacustres, lagoas, lagunas, lagoas interdunares e cordões de beachrocks (CLAUDINO-SALES, 2007). Devido essa diversidade de formas e a escala de análise da pesquisa, foi proposto uma setorização do litoral do Nordeste Setentrional, baseada nas feições que prevalecem em três setores distintos (Figura 9).

O Setor A, delimitado entre o litoral do baixo curso do rio Parnaíba até o litoral que bordeja a Serra do Mel no Rio Grande do Norte, sendo este caraterizado pela predominância e extensão dos materiais arenosos que demostram a atuação de climas secos, resultando na formação de campos de dunas barcanas, barcanóides, frontais, transversais e parabólicas (RADAMBRASIL, 1981a; MORAIS et al. 2006; VITAL et al. 2006). Duas formas erosivas predominam neste setor, os promontórios e as falésias.

Os promontórios, ou pontas litorâneas, mostram a influência dos materiais cristalinos Pré-Cambrianos no litoral, associados com a divisão da Pangea, sendo representados pelas pontas de Iguape, Mucuripe, Pecém e Jericoacoara (CLAUDINO-SALES, 2007). Os promontórios contribuem para a formação do litoral em zeta (em zigue-zague), com alternâncias entre pontas litorâneas e enseadas (CLAUDINO-SALES, 2007, 2006). As falésias, por sua vez, são modeladas nas camadas da Formação Barreiras, que representa o depósito correlativo da modelagem das superfícies de aplainamento.

O Setor B, entre a Serra do Mel até a desembocadura do rio Curimataú no Rio Grande do Norte, é caracterizado por um litoral em zeta, e com influências tectônicas do Cenozoico que atuaram na Formação Barreiras (VITAL et al. 2006). No litoral norte potiguar, os efeitos da neotectônica nas mudanças da morfologia costeira, atestam a influência do controle tectônico da reativação do Sistema de Falhas de Carnaubais e Afonso Bezerra na direção da abertura dos canais de maré (RIOS et al. 2016).

Devido sua localização, o setor B está sob diferentes dinâmicas climáticas, o que termina por alterar o deslocamento dos ventos e da deriva litorânea, influenciando na sua morfologia. Entre a Serra do Mel e o Cabo do Calcanhar predomina o clima semiárido, com transporte de sedimentos da direção leste para oeste e ocorrência de campos de dunas barcanas. Entre o Cabo do Calcanhar até desembocadura do Rio Curimataú, predomina o clima tropical úmido e subúmido (DINIZ e PEREIRA, 2015), com deslocamento de sedimentos de sul para norte, e presença de campos de dunas parabólicas.

No setor $\mathrm{C}$, entre as desembocaduras dos rios Curimataú e Capibaribe, predomina o clima tropical úmido, com planície litorânea mais estreita e ocorrência de relevos mamelonares do tipo colinas e mares de morros, localizados na zona costeira (AB'SABER, 1975; MOREIRA, 1977; CORREIA et al. 2010).

\subsubsection{Planícies Fluviais}

São unidades decorrentes da acumulação de sedimentos aluviais, depositados pela ação da rede de drenagem. No sertão nordestino essa unidade geomorfológica apresenta aspectos na dinâmica diferenciados do que ocorre em climas úmidos.

O caráter intermitente dos rios tem repercussão na própria gênese dos ambientes semiáridos, já que grande parte dos detritos fica à mercê dos processos erosivos nas calhas fluviais. Tal fato tem impacto na formação dos ambientes pediplanados, ou seja, o material despejado nos vales fica disponível para a ação pluvial subsequente (TWIDALE, 2000).

Segundo Souza (1988), no Ceará, essas áreas constituem áreas de diferenciação regional nos sertões semiáridos, por abrigarem melhores condições de solos e de disponibilidade hídricas. São áreas que acompanham, longitudinalmente, os maiores coletores de drenagem, a destacar os rios Jaguaribe, Acaraú e Banabuiú. Nestas áreas, para montante, as planícies têm larguras inexpressivas. Para jusante, nos baixos cursos, à medida que entalham terrenos da Formação Barreiras, a faixa de deposição é ampliada, a que se deve a diminuição do gradiente fluvial (SOUZA, 2007).

Além da dinâmica relacionada à deposição de sedimentos ao longo das calhas fluviais, o condicionamento dos vales pode estar relacionado ao controle estrutural associado a tectônica. São exemplos os vales estruturais representados pelos rios Jaguaribe, Apodi-Mossoró e Piranhas-Açu, que drenam seus deflúvios submetidos a um controle estrutural de drenagem em nível regional. Nas zonas de cisalhamento dispostas no sentido NE-SW, os rios seguem preferencialmente esta direção (MAIA et al. 2008). 


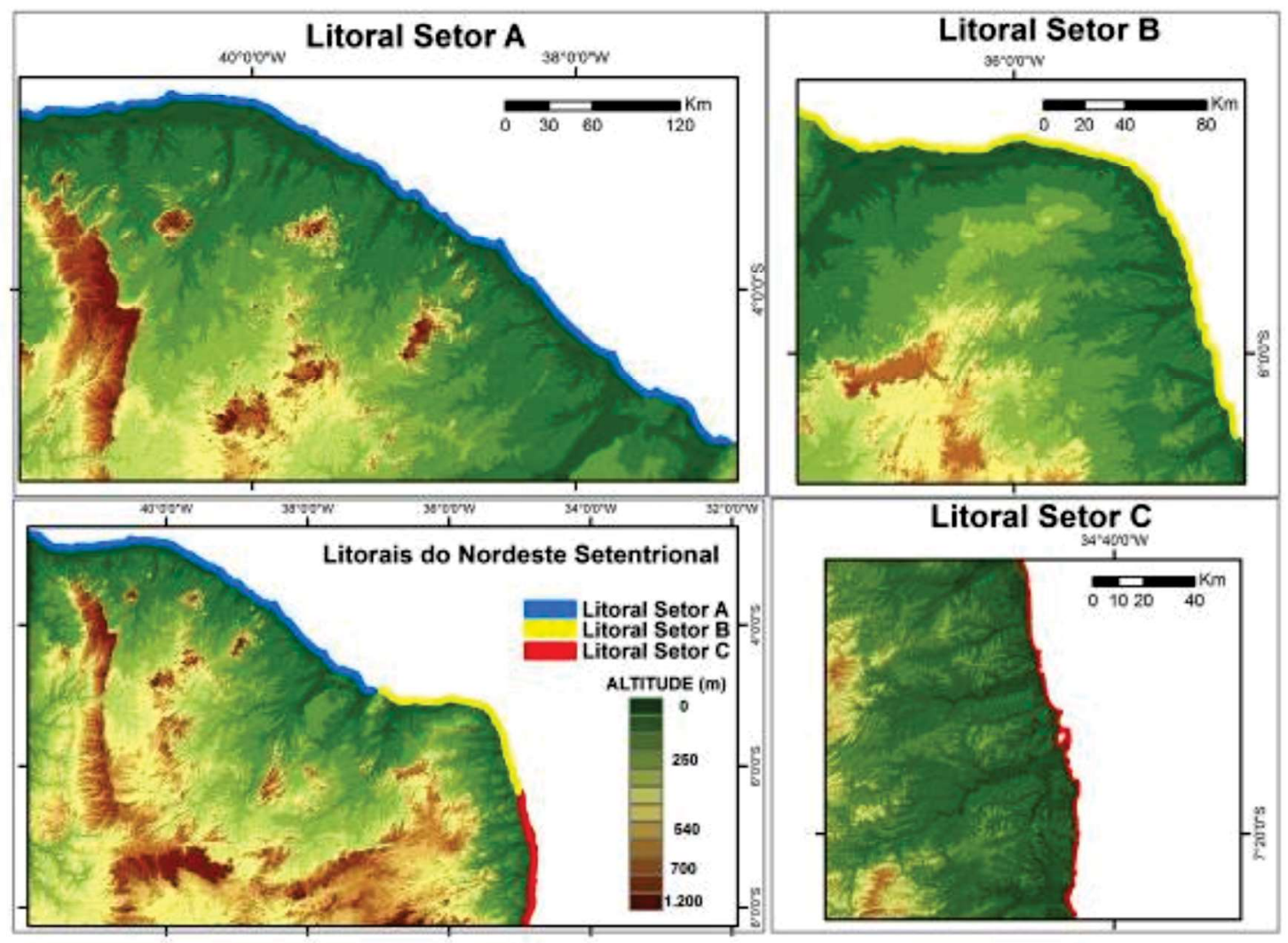

Figura 9 - Litorais do Nordeste Setentrional. Fonte: Elaborado a partir de dados SRTM.

No estado da Paraíba, a disposição dos vales fluviais, de forma semelhante a um teclado de piano, evidencia diferenças na altura dos tabuleiros, com vales encaixados apresentando um desnível em relação ao talvegue de mais de $100 \mathrm{~m}$ (FURRIER et al. 2006). Para estes mesmos autores, reativações pós-cretáceas geraram soerguimentos distintos e basculamentos de superfícies geomorfológicas, onde os inúmeros falhamentos dinamizaram entalhes e orientaram a dissecação.

Para além da dissecação, o condicionamento estrutural representado pelas zonas de cisalhamento sobre a drenagem tem influenciado a agradação originando pacotes aluviais orientados nos sentidos dos trends de deformação.

\subsubsection{Tabuleiros Costeiros}

São feições típicas da zona costeira, com relevo predominantemente tabular, produto da erosão ocorrida no continente que se acumulou na zona costeira. Constitui-se ainda como uma unidade de transição do interior para a costa, evidenciada pela baixa declividade em relação as Superfícies Sertaneja e Pré-litorânea.
Os Tabuleiros Costeiros são sustentados pela Formação Barreiras, essa de origem continental, transicional e marinha (ARAI, 2005), com de idade entre 23 e 17Ma (LIMA, 2008). Apresenta matriz argilosa com bolsões e/ou níveis de seixos, na maioria dos afloramentos ocorrem porções ferruginosas e concreções lateríticas. Em alguns afloramentos são verificados blocos de calcedônia, indicando níveis onde ocorreu silicificação mais intensa (LIMA, 2008). Normalmente essa unidade litoestratigráfica encontra-se bem consolidada e recoberta por uma camada cascalhosa ou crosta laterítica.

No Ceará, a Formação Barreiras recobre o embasamento com formas predominantemente tabulares e cortadas pela rede de drenagem. Cabe destacar a Formação Camocim, sustentando falésias na foz do Rio Coreaú, no norte do estado do Ceará (COSTA et al. 1973; MORAIS et al. 2006). No Rio Grande do Norte recobre a Formação Jandaíra da Bacia Potiguar e o embasamento Pré-Cambriano na porção leste do estado. Na Paraíba e Pernambuco, os Tabuleiros Costeiros desenvolvem-se sobre os sedimentos da Formação Barreiras e das rochas sedimentares do Grupo Paraíba, com feições colinosas do tipo mares de morro (AB'SABER, 1975), prove- 
niente da dissecação da rede de drenagem em resposta as condições climáticas mais úmidas.

Dentre as unidades geomorfológicas apresentadas, são as que melhor apresentam dados estruturais mais recentes, associados a neotectônica. Esses dados são encontrados sobretudo na forma de deformações como dobramentos, falhamentos e sismitos. Esses últimos são muito expressivos nos litorais paraibano e potiguar. Quanto à influência de macroescala, Furrier et al. (2006) demonstraram os efeitos da tectônica no litoral da Paraíba através da análise da rede de drenagem nos tabuleiros costeiros. As análises no litoral paraibano evidenciam a atuação da tectônica Cenozoica na movimentação de blocos, influenciados por antigos falhamentos, atuando na disposição do relevo em diferentes cotas altimétricas e consequentemente no padrão de dissecação (FURRIER et al. 2006).

Vale ressaltar as feições tabuliformes recentes no interior do continente, denominadas de Tabuleiros Interiores. Localizam-se de forma dispersa, principalmente no estado do Ceará, caracterizados litologicamente pelos depósitos aluviais antigos da Formação Faceira e de coberturas colúvio-eluviais detríticas (BRAGA et al. 1981; SOUZA, 2007).

\subsubsection{Superfícies sedimentares rebaixadas}

São áreas marcadas pela atuação da tectônica Cretácea sobre o relevo do Nordeste Setentrional
(MARINHO, 1979; VASCONCELOS e GOMES, 1998; PEULVAST e CLAUDINO-SALES, 2003, 2004, 2005; GALVÃO et al. 2005). São feições, predominantemente, de topo plano que ocorrem sobre os pacotes sedimentares Mesozoicos das bacias intracratônicas que compõem o Grupo Iguatu, as Formações Icó e Malhada Vermelha, a Formação Lima Campos e as Bacias do Rio do Peixe, classificadas como bacias interiores do tipo strike-slip (SILVA et al. 2003). A gênese desses ambientes está relacionada com a fissão entre a África e América do Sul, separando o supercontinente Gondwana (CARVALHO, 2000; CLAUDINO-SALES e PEULVAST, 2007).

Do ponto de vista da morfologia, essa unidade apresenta topografia plana a levemente ondulada, constituindo-se como um ambiente de agradação. A gênese dessas áreas está relacionada com a instalação de pequenos riftes na Província Borborema, que formaram lagos tectônicos que captavam a rede de drenagem subatual e sedimentos (CARVALHO e MELO, 2012). Assim, resultou na formação de bacias com materiais sedimentares continentais, cujas as espessuras são de 2.000 metros, no Rio do Peixe (GALVÃO et al. 2005), e de 1.760 metros na Bacia do Iguatu (SILVA et al. 2003).

Esta unidade de relevo possui níveis altimétricos inferiores as unidades geomorfológicas adjacentes, como é visto na figura 10. A diferença altimétrica pode alcançar até $120 \mathrm{~m}$, sendo classificadas por Marinho (1979) e Vasconcelos e Gomes (1998) como baixadas.

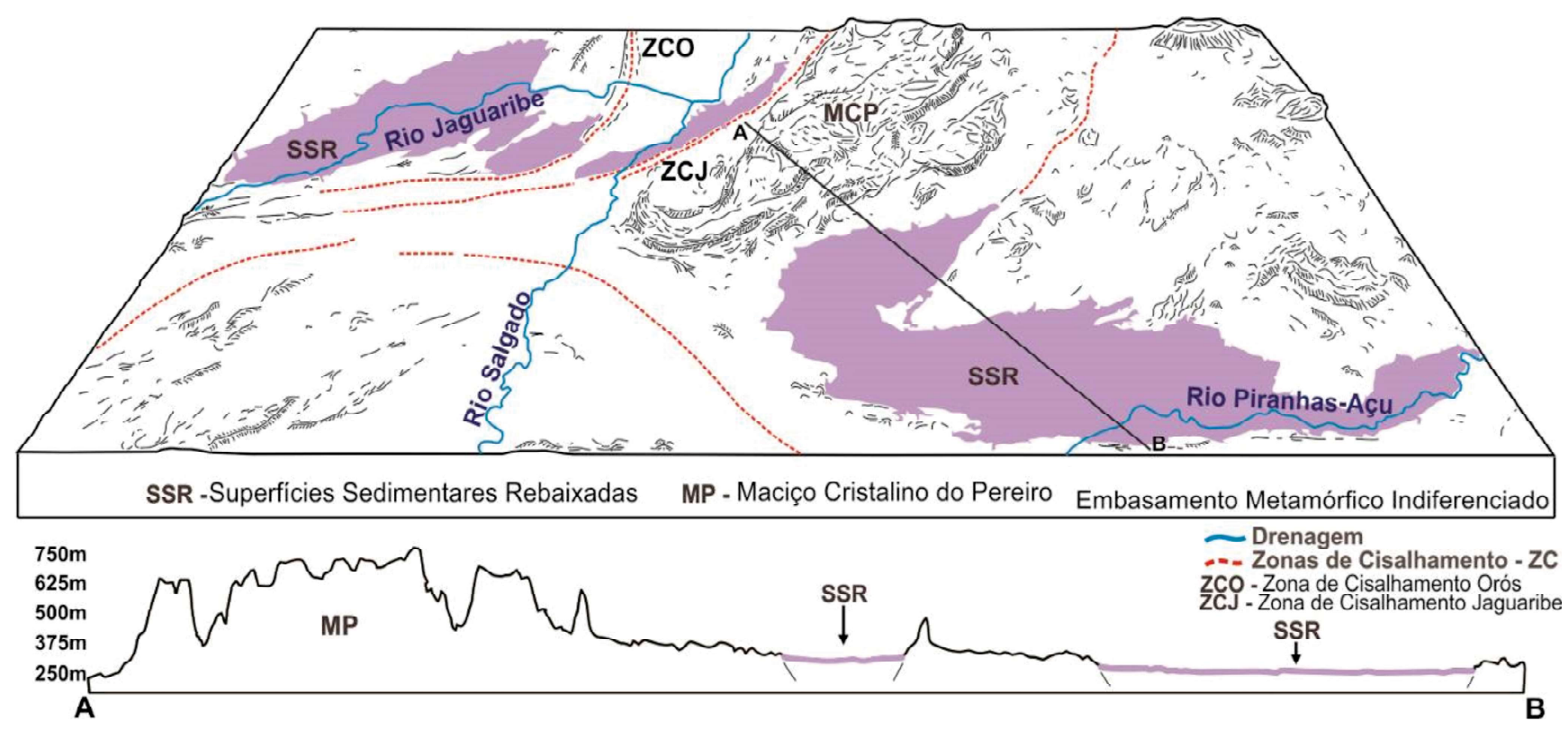

Figura 10 - Bloco diagrama representativo da unidade de geomorfológica das Superfícies Sedimentares Rebaixadas e adjacências. 


\subsection{Formas de Abrangência Espacial Restrita}

Representam feições dispersas no Nordeste Setentrional, constituindo-se de morfologias distintas, com a formação de cânions, boqueirões, colinas, domos, relevos vulcânicos e relevos cársticos.

\subsubsection{Cânions e boqueirões}

Foram identificados três cânions na área de pesquisa: Poti, Apodi-Mossoró e Apertados, drenados pelos rios Poti, Apodi-Mossoró e Picuí respectivamente. São feições que comprovam o poder erosivo da rede de drenagem, gerando grandes paredões em rochas sedimentares nos cânions do Rio Poti (BARRETO e COSTA, 2014) e Apodi-Mossoró (MAIA e BEZERRA, 2014), e em rochas quartizíticas na região do Cânion dos Apertados (MEDEIROS e OLIVEIRA, 2011).

Os boqueirões são formas fluviais erosivas em que a drenagem corta os materiais cristalinos sobre forma de cristas, sendo assim, feições erosivas de pouca extensão, porém relevantes no entendimento da evolução da região, considerando-se que a dissecação atinge o nível de base de erosão representado pela Superfície Sertaneja, o que certamente contribuiu para sua evolução. Isso é evidente nos boqueirões de Arneiroz e de Banabuiú, oriundos da atuação dos Rios Jaguaribe e Banabuiú respectivamente, esculpidos em cristas estruturais orientadas pelas Zonas de Cisalhamento Senador Pompeu e Orós.

\subsubsection{Colinas}

Localizam-se na área da Superfície Pré-litorânea e dos Tabuleiros Costeiros. Esta área apresenta níveis de dissecação desencadeados pela drenagem, fato provocado principalmente pela perenidade dos rios locais. Do ponto de vista morfoclimático correspondem as áreas dos mares de morros (AB'SABER, 1975; MOREIRA, 1977). Assim, colinas típicas são formadas pela dissecação fluvial mais intensa, principalmente nas áreas que correspondem aos estados da Paraíba e Pernambuco, quando as condições de semiaridez atenuam-se.

\subsubsection{Domos}

Os domos são formas de relevo com típica expressão em abóbadas. $\mathrm{Na}$ porção norte do Rio
Grande do Norte destacam-se os domos da Serra do Mel e do Mangue Seco, resultado da compressão E-W de estruturas do Neógeno-Quaternário (RIOS et al. 2016). O primeiro é caracterizado por apresentar uma topografia alongada no sentido NE-SW e está situado na porção central da Bacia Potiguar, chegando a atingir 270m de altitude (MAIA, 2012; MAIA e BEZERRA, 2014).

\subsubsection{Relevos vulcânicos}

São formas com pouca extensão, geralmente com topos irregulares, vertentes íngremes e constituídos por materiais oriundos dos vulcanismos Messejana e Macau (Cenozoico), no Ceará e Rio Grande do Norte. Costa (2008) salienta que a gênese e localização destes edifícios vulcânicos estaria relacionada com atuação de hot spot, o mesmo que gerou o Arquipélago de Fernando de Noronha, onde, posteriormente, a erosão removeu as partes externas, deixando exposto, na atualidade, as antigas chaminés.

\subsubsection{Relevos cársticos}

Ocorrem de forma dispersa na área de pesquisa, caracterizados como todas as feições erosionais elaboradas pelos processos de dissolução, corrosão e abatimento que ocorrem em rochas solúveis (PILÓ, 2000; DE WAELE et al. 2009; KLIMCHOUCK, 2009; TRAVASSOS, 2019).

Na região da bacia Potiguar têm-se as mais notáveis ocorrências dessas morfologias. Repercutem no relevo na forma de cavernas, dolinas, vales cársticos, campos de lapiás, karrens e lajedos. Trata-se de um conjunto de relevos desenvolvidos segundo as direções dos principais sistemas de falhas regionais que afetam a Bacia Potiguar (MAIA et al. 2012).

Atualmente esses sistemas de falhas exercem importante influência na evolução geomorfológica desta bacia, uma vez que controlam a drenagem e direcionam a dissecação e a deposição de sedimentos Quaternários (MOURA-LIMA et al. 2011; MAIA e BEZERRA, 2012). Na figura 11 é apresentada a compartimentação geomorfológica da área analisada. 




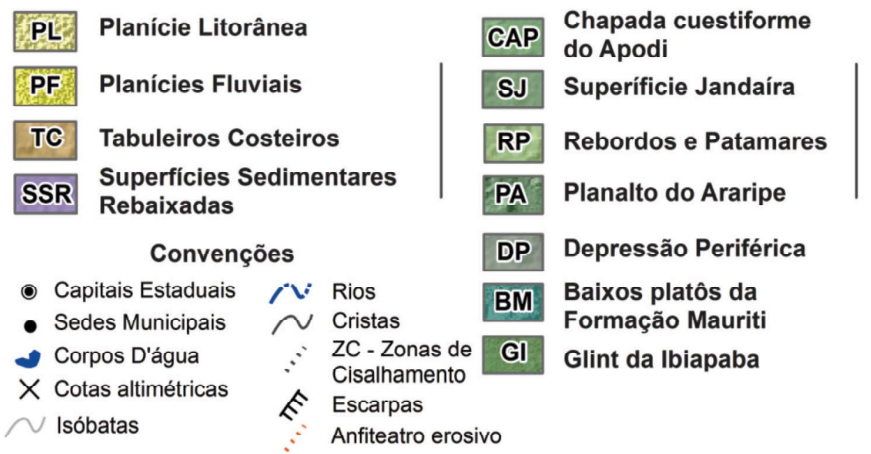

SS1 Superfície Sertaneja 1 MB Maciço da Borborema

SS2 Superfície Sertaneja 2

SPL Superfície Pré-litorânea

MC Maciços Cristalinos

MC1: Maciços do CE central MC2: Maciços do Alto Jaguaribe MC3: Maciço do Pereiro MC4: Maciço de Baturité MC5: Maciço de Uruburetama MC6: Maciço da Meruoca

Formas de abrangência espacial restrita

$\begin{array}{ll}\text { A Cânions } & \text { Colinas } \\ \text { ][ Boqueirão Relevos Vulcânicos }\end{array}$

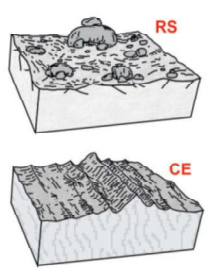

RS - Relevo Saprolitico PPM - Pequenos platôs
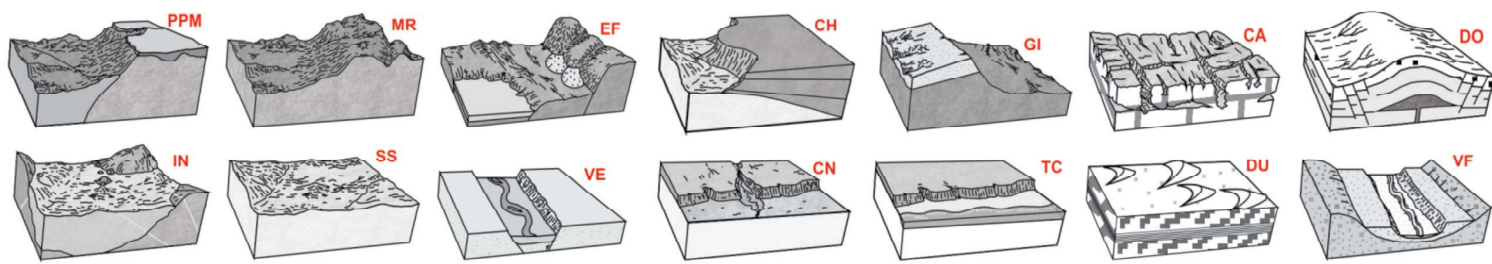

MC - Maciços Cristalinos CH - Chapadas CA - Carste CE - Cristas Estruturais SS - Superfície Sertaneja CN - Cânion

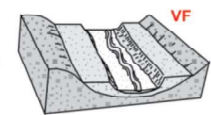

DU - Dunas

EF - Escarpa de Falha GI - Glint

DO - Domo IN - Inselbergues

VE - Vales Estruturai

TC - Tabuleiros Costeiros VF - Vales Fluviais

Figura 11 - Geomorfologia do Nordeste Setentrional 


\section{Discussões}

A disposição do relevo da região Nordeste foi interpretada como superfícies escalonadas, resultado do processo de pediplanação (KING, 1956), com a morfologia como resposta ao soerguimento uniforme e concomitante, com o desenvolvimento de superfícies de erosão (AB' SÁBER e BIGARELLA, 1961; AB'SABER, 1969b; BIGARELLA, 2003; ANDRADE e LINS, 1965; MABESOONE e CASTRO, 1975).

Eram modelos que em termos de evolução geomorfológica tinha uma ênfase na dinâmica do Quaternário, com destaque para a geomorfologia climática (AB'SABER, 1969c). Em contraposição, atualmente a interpretação do relevo anterior ao Quaternário adquire espaço, onde tem-se constatado em trabalhos (PEULVAST e CLAUDINO-
-SALES, 2004; FURRIER et al. 2006; BEZERRA et al. 2008; MAIA et al. 2010; GURGEL et al. 2013; MAIA e BEZERRA, 2014; CLAUDINO-SALES, 2016) que as superfícies de erosão na porção setentrional do NE tem origem poligênica, com influência de diversos fatores, com destaque para a tectônica Cretácea rifte e pós-rifte, além da erosão diferencial ao longo das zonas de cizalhamento.

Tal fato é justificável, pois paleosuperfícies agradacionais e de gênese e idades semelhantes estão dispostas em cotas distintas (Figura 12), como é o caso da superfície Albiana-Cenomaniana da seção pós-rifte da Bacia Potiguar e Bacia do Araripe, a primeira com cota não ultrapassando $180 \mathrm{~m}$ e a segunda chegando a $900 \mathrm{~m}$ (PEULVAST e CLAUDINO SALES, 2004).

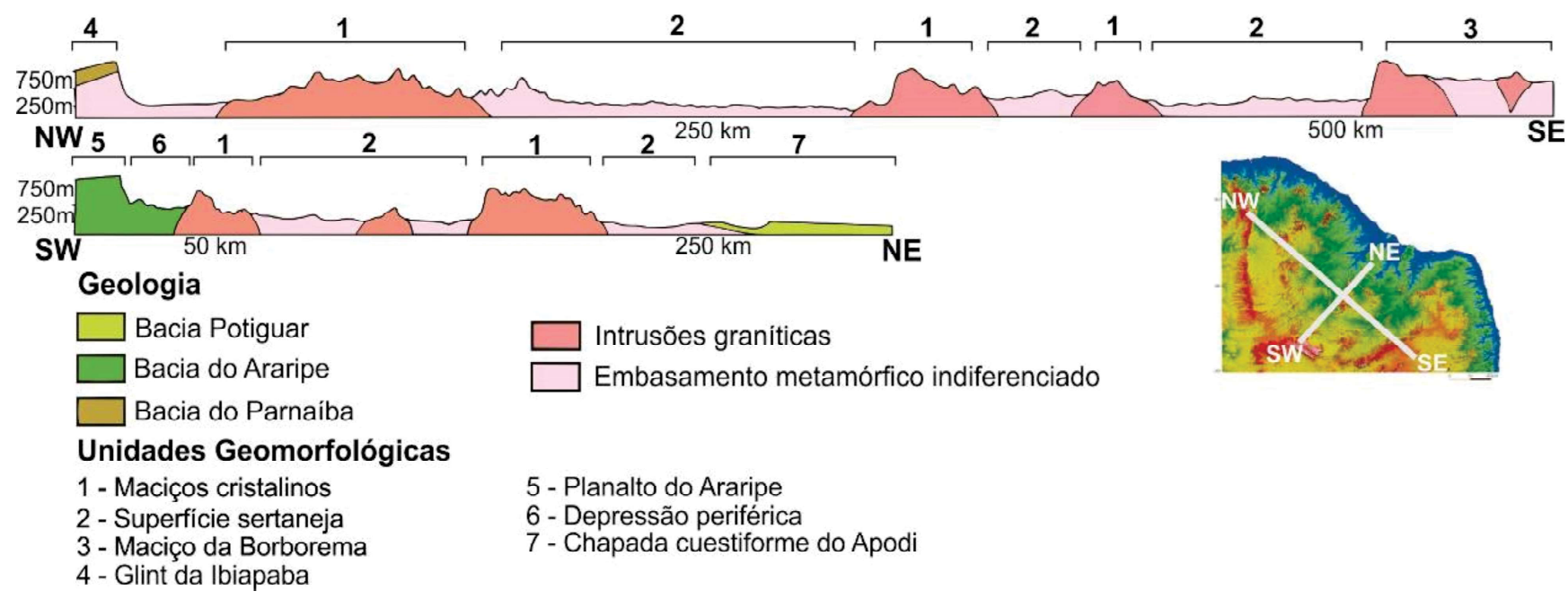

Figura 12 - Perfis geológico-geomorfológicos da área de estudo

Dessa forma, o modelo de pediplanação, ainda largamente utilizada como base única para a interpretação do relevo do Nordeste Brasileiro, se contrapõem as novas técnicas de interpretação da morfologia, onde as análises, além de topográficas, incluem indicadores morfoestratigráficos e morfotectônicos (MAIA et al. 2010).

No NE setentrional, os compartimentos são representados por um conjunto de morfologias herdadas da estruturação Pré-Cambriana e Cretácea, reativadas por vezes no Cenozoico. Essa estruturação se inicia, em termos genéticos, a partir da orogênese Brasiliana no Neoproterozóico (BRITO NEVES, 1999) e a tectônica que culminou com a separação do megacontinente Gondwana no Jurássico-Cretáceo (PEULVAST e CLAUDINO SALES, 2004). Ambos foram responsáveis pela geração de extensas zonas de cizalhamento dúcteis de direção NE-SW e NW-SE (ALMEIDA et al. 2000; BRITO NEVES, 1999) que atualmente exercem importante controle sobre feições da morfologia (MAIA e BEZERRA, 2014).

Estes autores incorporaram na descrição do relevo os processos estruturais referentes à tectônica Mesozoica e Cenozoica, em particular os eventos de natureza estrutural, dados a partir de rifteamento e posterior divisão de Gondwana no Cretáceo médio e 
atividade tectônica associada. Tais análises envelhecem sobremaneira a idade de grande parcela do relevo regional, saindo do Paleógeno e Neógeno classicamente considerado na literatura anterior para o Cretáceo, tendo ainda alguns elementos datando do Paleozoico e Pré-Cambriano (CLAUDINO-SALES, 2002; PEULVAST e CLAUDINO-SALES, 2004).

Esses processos pretéritos foram responsáveis pela formação, entre a Bacia do Parnaíba e o Maciço da Borborema, de um vasto anfiteatro de $450 \mathrm{~km}$ aberto em direção ao mar (ver figura 9). Este anfiteatro comporta-se atualmente um conjunto complexo de formas estruturais soerguidas em direção ao sul e amplamente trabalhadas pela erosão (a zona de rifting Cariri/Potiguar), com platôs tabulares, bacias de afundamento e corredores de erosão diferencial bordejadas por relevos herdados de falhas (PEULVAST e CLAUDINO SALES, 2004).

Dessa forma, a herança Mesozoica, decorrente do rifteamento que separou América do Sul da África, proporcionou o arcabouço para a atuação dos processos denudacionais Cenozoicos. Tais processos acabaram por gerar distintas unidades geomorfológicas, comandadas principalmente pela dissecação fluvial, com exposição e mobilização do manto de alteração decorrente das variações climáticas Cenozoicas. A atividade tectônica Cenozoica também contribuiu para a evolução de várias das feições presentes nas diferentes unidades geomorfológicas identificadas na área de estudo, incidindo sobre o arcabouço Mesozoico e denudacional pré-existente (MAIA e BEZERRA, 2014).

\section{Considerações Finais}

O presente trabalho procurou contribuir para a compreensão da geomorfologia do Nordeste brasileiro nos aspectos metodológicos e evolutivos. No aspecto metodológico, a proposta tem o caráter multiescalar e multiprocessual, possibilitando representar feições de diferentes dimensões espaciais e evidenciar que os aspectos estruturais e tectônicos, além dos denudacionais e agradacionais, contribuem na delimitação de unidades de relevo de escala de detalhe.

Assim, a proposta de mapeamento geomorfológico para a área levou em consideração a integração entre processo e forma, distinguindo o relevo nas seguintes macronunidades: Formas Denudacionais, Formas Circudenudacionais e Formas Agradacionais. Tais unidades geomorfológicas, apesar de classificadas segundo a ocorrência de processos associados com erosão, transporte e deposição, ou seja, com processos comandados sobretudo por ações externas, são apresentadas segundo o processo gerador com ênfase na estrutura e na tectônica, que são, por sua vez, controlados basicamente por ações internas.

$\mathrm{Na}$ análise apresentada, a denudação continental distinguiu as formas de relevo a partir do condicionamento morfoestrutural representado pelas zonas de deformação rúpteis e dúcteis do embasamento cristalino Pré-Cambriano. Tal processo revelou em superfície as estruturas da crosta, que atualmente condicionam as formas de relevo através da erosão diferencial. A partir desse processo, as formas agradacionais se instalaram nas áreas mais rebaixadas, auxiliadas por processos de escoamento fluvial e superficial, além de interferências eustáticas que influenciaram a erosão e agradação na zona costeira. As formas circudenudacionais, controladas por litologias sedimentares, retraíram-se a medida que os processos erosivos evoluíam, exibindo o front de alteração.

A relação entre morfoestrutura e elementos morfoclimáticos é nitidamente observada nas superfícies de aplainamento (Superfícies Sertaneja 1, 2 e Pré-litorânea), maior unidade de relevo da área, testemunhando ações pretéritas e atuais da denudação continental, controlando a localização dispersa das cristas e inselbergues, e demarcando a diferença altimétrica em relação a unidades de relevos como o Glint da Ibiapaba, o Planalto do Araripe, a Chapada do Apodi e os maciços cristalinos, incluindo o Maciço da Borborema. A evolução das superfícies de aplainamento definida por essa relação entre morfoestrutura e elementos morfoclimáticos em parte explica também os processos de agradação que prevaleceram no litoral ao longo da evolução pós-cretácea, os quais acham-se também associados com a flexura marginal.

Assim, a proposta de mapeamento ora apresentada, associada com as análises expostas acerca da origem e evolução da morfologia regional, além de abarcar os processos de caráter geomorfológico, identifica também classes de relevos, mostrando-se como um importante elemento de conhecimento das características do meio físico do Nordeste setentrional brasileiro.

Com efeito, a partir da apresentação das formas de relevo e processos associados, outros elementos do meio natural podem ser melhor entendidos, tais como 
a evolução dos solos e, a partir daí, a implantação das coberturas vegetais e respectivos ecossistemas. O mapeamento apresentado, enquanto representação cartográfica da reconstituição da história da paisagem geomorfológica natural, pode também dar suporte para o planejamento ambiental e regional, fornecendo subsídios que possibilitem intervenções no espaço natural que sejam menos invasivas e degradadoras das qualidades intrínsecas do espaço físico e do meio ambiente de forma geral.

\section{Referências Bibliográficas}

AB' SÁBER, A.N; BIGARELLA, J.J. Considerações sobre a geomorfogênese da Serra do Mar. Boletim Paranaense de Geografia n.4/5 p94-110, 1961.

AB'SABER, A. N. A depressão periférica paulista: um setor das áreas de circundesnudação pós-cretácica na Bacia do Paraná. Geomorfologia, n.15, p.1-15, 1969a

AB' SÁBER, A. N. Participação das superfícies aplainadas nas paisagens do Nordeste Brasileiro. Boletim de Geomorfologia, IGEOG-USP, SP, n 19, 38p. 1969 b.

AB' SÁBER, A.N. Um conceito de Geomorfologia a serviço das pesquisas sobre o Quaternário. Geomorfologia, São Paulo, 18:1-23, 1969c.

AB'SABER, A. N. Formas de relevo: texto básico. Edart. São Paulo, 1975.

ALMEIDA, F. F. M.; BRITO NEVES, B.B.; CARNEIRO, C.D.R. The origin and evolution of the South American Platform. Earth Science Reviews, 50: 77-111, 2000.

ALMEIDA, A.R; ULBRICH, H.G.J. O Batólito Granítico Quixeramobim-Ce. Aspectos estruturais internos e mecanismo de alojamento crustal. Revista de Geologia UFC, Fortaleza, CE, 2003.

ANDRADE G.O; LINS R. Introdução à morfoclimatologia do Nordeste do Brasil. Arquivos do Instituto de Ciências da Terra, Recife (3-4): 11-28, 1965.

ARTHAUD, M.H. Evolução Neoproterozóica do Grupo Ceará (Domínio Ceará Central, NE Brasil): da sedimentação à colisão continental brasiliana. Tese (Doutorado em Geociências) Instituto de Geociências da Universidade de Brasília. Brasília, 2007.

ARAI, M. A grande elevação eustática do Mioceno: a ver dadeira origem do Grupo Barreiras. In: CONGRESSO
DA ASSOCIAÇÃO BRASILEIRA DE ESTUDOS DO QUATERNÁRIO. Guarapari. Anais...Guarapari: ABEQUA, 2005.

BAHIA, R. B. C.; LOPES, R. C; SILVA,A. J. P.; VASCONCELOS A. M. Bacias sedimentares paleozóicas e meso-cenozóicas interiores. In: Bizzi L. A.; Gonçalves J. H.; Schobbenhaus C.; Vidotti R. M. (eds.) Geologia, Tectônica e Recursos Minerais do Brasil. Brasília: CPRM, 2003.

BARBOSA, G. V; SILVA, T. C; FILHO, T. N; DEL'ARCO, D. M; COSTA, R. C. R. Evolução da metodologia para mapeamento geomorfológico do projeto RADAMBRASIL. Salvador: Projeto RADAMBRASIL. (Boletim técnico do Projeto RADAMBRASIL. Série Geomorfologia), 1984.

BARRETO, L. L.; COSTA, L. R. F. Evolução geomorfológica e condicionantes morfoestruturais do cânion do rio Poti - Nordeste do Brasil. Revista Brasileira de Geomorfologia, v. 15, n. 3, p. 411-424, 2014.

BASTOS, F. H. Movimentos de massa no maciço de Baturité (CE) e contribuições para estratégias de planejamento ambiental. Tese (Doutorado em Geografia) - Curso de Pós-Graduação em Geografia, Universidade Federal do Ceará, Fortaleza, 2012. BÉTARD, F., PEULVAST, J.P., CLAUDINO SALES, V. Laterite preservation and soil distribution in the Araripe-Campos Sales area, Northeastern Brazil: consequences of uplift, erosion and climatic change. 6th International Conference on Geomorphology, Zaragoza, September 7-11, Abstracts Volume, p. 69.2005.

BÉTARD, F.; PEULVAST, J. P. Evolução morfoestrutural e morfopedológica do Maciço de Baturité e seu Piemont: do Cretáceo ao Presente. In: BASTOS, F. H.(org.) Serra de Baturité: uma visão integrada das Questões ambientais. Fortaleza: Expressão Gráfica e Editora, 2011.

BEZERRA, F. H. R.; NEVES, B. B. B.; CORREA, A. C. B.; BARRETO, A. M. F.; SUGUIO, K. Late Pleistocene tectonicgeomorphological development within a passive margin - the Cariatá trough, northeastern Brazil. Geomorphology. 01: 555582, 2008.

BIGARELLA, J. J. Estrutura e Origem das Paisagens Tropicais. Vol.3. Florianópolis: Ed. UFSC. 2003.

BRAGA, A. P.G; PASSOS, C. A. B; SOUZA, E. M; FRANÇA, J. B; MEDEIROS, M. F; ANDRADE, V. A. Geologia da Região Nordeste do Estado do Ceará. Projeto Fortaleza. DNPM, Brasília, 1981.

BRITO NEVES, B. B. América do Sul: quatro fusões, quatro 
fissões e o processo acrescionário andino. Revista Brasileira de Geociências. Vol 29, p. 379-292, 1999.

CARVALHO, I. S. Bacias intracratônicas do Nordeste do Brasil. In: BRITO, I. M. (Org.). Geologia Histórica. 1ed. Uberlândia: Universidade Federal de Uberlândia, 2000.

CARVALHO, I. S.; MELO, J. H. G. Bacias Interiores do Nordeste. In: HASUI, Y.; CARNEIRO, C. D. R.; ALMEIDA, F. F. M.; BARTORELLI, A. (Org.) Geologia do Brasil. 1ed.São Paulo: Beca Editora, 2012.

CLAUDINO-SALES, V. C. Les Littoraux du Ceará. Evolution géomorphologique de la zone côtière de L'Etat du Ceará, Brésildu long terme au court terme. Thése de Doctorat, Université Paris Sorbonne, Paris.2002.

CLAUDINO-SALES, V. C. Os litorais cearenses. In: SILVA, J. B.; CALVACANTE, C. T.; DANTAS, E. W. C. (orgs). Ceará: um novo olhar geográfico. 2 ed. Fortaleza: Edições Demócrito Rocha, 2007.

ClAudinO-SAlES, V. C.; PEUlvast, J. P. Evolução morfoestrutural do relevo da margem continental do Estado do Ceará, Nordeste do Brasil. Caminhos de Geografia (UFU), v.8, p. 2-22, 2007.

CLAUDINO-SALES, V. C. Megageomorfologia do Estado do Ceará. Novas edições Acadêmicas, 2016.

C LA U D IN O-S A LES, V. C; LIRA, M . C . Megageomorfologia do Noroeste do estado do Ceará, Brasil. Revista Caminhos de Geografia - UFU (Uberlândia-MG), v. 12, n 38, p. 200-209, 2011.

CORREA, A. C. B.; TAVARES, B. DE A. C.; MONTEIRO, K. A.; CAVALCANTI, L. C. S.; LIRA, D. R. Megageomorfologia e morfoestrutura do Planalto da Borborema. Revista do Instituto Geológico, v. 31, p. 35-52, 2010.

CORSINI, M., LAMBERT DE FIGUEIREDO, L., CABY, R., FÉRAUD, G., RUFFET, G., VAUCHES, A., Thermal history of the Pan/African - Brasiliano Borborema province of the northeast Brazil, deduced from40AR/39AR analysis. Tectonophysics, 285, 1998.

COSTA, A. T. Estudo morfoambiental dos relevos Vulcânicos da Região Metropolitana de Fortaleza. Dissertação (Mestrado em Geografia) - Curso de Pós-Graduação em Geografia, Universidade Federal do Ceará. Fortaleza, 2008.

COSTA, M.J.; FRANÇA, J.B.; LINS, C.A.C.; BACCHIEGGA, I.F.; HABEKOST, C.R.; CRUZ, W.B. Geologia da Bacia de Jaibaras, Ceará, Piauí, Maranhão. Brasília, MME/DNPM. bol. 11. 140p. (Série Geológica Básica), 1973.
CPRM - Serviço geológico do Brasil. Mapa Geológico do Estado do Ceará. Escala 1:500.000, Ceará. CPRM, 2003.

CPRM - Serviço geológico do Brasil. Mapa Geodiversidade do Estado do Rio Grande do Norte. Natal: CPRM, 2009. Escala: 1:500.000.

CPRM - Serviço geológico do Brasil. Mapa Geodiversidade do Estado do Ceará. Fortaleza: CPRM, 2010a. Escala: 1:750.000.

CPRM - Serviço geológico do Brasil. Mapa Geodiversidade do Estado do Piauí. Teresina: CPRM, 2010b. Escala: 1:1. 000.000.

CPRM - Serviço geológico do Brasil. Mapa Geodiversidade do Estado do Pernambuco. Recife: CPRM, 2010c. Escala: 1:500.000.

CPRM - Serviço geológico do Brasil. Mapa Geodiversidade do Estado do Paraíba. João Pessoa: CPRM, 2013. Escala: 1:500.000.

DE CASTRO, D. L.; BEZERRA, F. H.R.; SOUSA, MARIA O.L.; FUCK, R. A. Influence of Neoproterozoic tectonic fabric on the origin of the Potiguar Basin, northeastern Brazil and its links with West Africa based on gravity and magnetic data. Journal of Geodynamics, v. 54, p. 29-42, 2012.

DE WAELE, J. D; PLAN, L; AUDRA, P. Recent developments in surface and subsurface karst geomorphology: An introduction. Geomorphology, v. 106, p. 1-8, 2009.

DINIZ, M. T. M; PEREIRA, V. H. V. Climatologia do estado do Rio Grande do Norte, Brasil: sistemas atmosféricos atuantes e mapeamento de tipos de clima. Revista Boletim Goiano de Geografia. v. 35, n. 3, p. 488-506, 2015.

FURRIER, M.;ARAÚJO, M.E.; MENESES, L. F. Geomorfologia e Tectônica da Formação Barreiras no Estado da Paraíba. Geologia USP, Sér. Cient., São Paulo, v.6, n.2, p. 61-70, 2006.

GALVÃO, M. J. T. G.; SRINIVASAN V. S.; SCHUSTER, H. D. M. REGO, J. C. ALBUQUERQUE, J. P. T. Comportamento das bacias sedimentares da região semi-árida do Nordeste brasileiro. Hidrogeologia da Bacia Sedimentar do Rio do Peixe. Recife: CPRM/UFCG/FINEP, 2005.

GURGEL, S. P. P. Evolução Morfotectônica do Maciço Estrutural Pereiro, Província Borborema. Tese (Doutorado em Geodinâmica e Geofísica) - Curso de Programa de PósGraduação em Geodinâmica e Geofísica, Universidade Federal do Rio Grande do Norte, Natal, 2012.

GURGEL, S. P. P.; BEZERRA, F. H. R.; CORRÊA, A. C.B.; MARQUES, F O.; MAIA, R. P. Cenozoic uplift and erosion of structural landforms in NE Brazil. Geomorphology 
(Amsterdam), v. 186, p. 68, 2013.

IBGE. Manual técnico de geomorfologia, Coordenação de Recursos Naturais e Estudos Ambientais. - 2. ed. - Rio de Janeiro: IBGE, 2009.

KING, L. C. A Geomorfologia do Brasil Oriental. Revista Brasileira de Geografia. v. 18, n. 2, p. 147-265, 1956.

KLIMCHOUCK, A. Morphogenesis of hypogenic caves. Geomorphology, v. 106, Issues 1-2, p.100-117, 2009.

LIMA, M.G. A história do intemperismo na Província Borborema Oriental, Nordeste do Brasil: implicações paleoclimáticas e tectônicas.. Tese (Doutorado em Geodinâmica e Geofísica) - Curso de Programa de Pós-Graduação em Geodinâmica e Geofísica, Universidade Federal do Rio Grande do Norte, 2008.

MABESSONE, J. M; CASTRO, C; Desenvolvimento Geomorfológico do Nordeste Brasileiro, Boletim do núcleo Nordeste da Sociedade Brasileira de Geologia. 3, 1975.

MAIA, R. P.; BEZERRA, F. H; CLAUDINO-SALES, V. C. Vales Fluviais do NE: Considerações Geomorfológicas. Okara : Geografia em Debate (UFPB), 2008.

MAIA, R. P.; BEZERRA, F. H.; CLAUDINO-SALES, V. C. Geomorfologia do Nordeste: Concepções clássicas e atuais acerca das superfícies de aplainamento. Revista de Geografia (Recife), v. 27, p. -6--19. 2010.

MAIA, R. P.; BEZERRA, F.H.B. Geomorfologia e Neotectônica da Bacia Hidrográfica do Rio Apodi-Mossoró NE/Brasil. Mercator (Fortaleza. Online), v. 11, p. 209-228, 2012.

MAIA, R. P.; SOUZA, M.O.L.; BEZERRA, F.H.B.; XAVIER NETO, P.; SILVA, C.C.N. DA; MOURA-LIMA, E.N.; SANTOS, R.D. A importância do controle tectônico para a formação da paisagem cárstica na Bacia Potiguar, Nordeste do Brasil. Revista Brasileira de Geomorfologia, v. 13, nº 4 p.451-463, 2012.

MAIA, R. P.; BEZERRA, F. H. B. Tópicos de geomorfologia estrutural: nordeste brasileiro. Fortaleza: Edições UFC, 2014.

MAIA, R. P; BÉTARD, F; BEZERRA, F.H.R. Geomorfologia dos Maciços de Portalegre e Martins - NE do Brasil: Inversão do relevo em análise. Revista Brasileira de Geomorfologia. v 17. n 2, 2016.

MARINHO, A. G. S. História cenozóica da bacia de Sousa. Dissertação de Mestrado. Recife, 1979.

MARQUES, F.O; NOGUEIRA, F.C.C; BEZERRA, F.H.C; CASTRO, D.L. The Araripe Basin in NE Brazil: An intracontinental graben inverted to a high-standing horst.
Tectonophysics. v. 630: 251-264, 2014.

MATOS, R.D.M. Tectonic evolution of the equatorial south atlantic, in: Atlantic Rift in Continental Margins. American Geophysical Union. p.331-351, 2000.

MEDEIROS, W. D. A; OLIVEIRA, F. F. G. Geodiversidade, geopatrimônio e geoturismo no município de Currais Novos/ RN, Nordeste do Brasil. Mercator (Fortaleza. Online), v. 10, p. 59-69, 2011.

MEIRELES, A. J. A. Geomorfologia costeira: funções ambientais e sociais. 2. ed. Fortaleza: Edicões UFC, 2014. 489p.

MOURA-FÉ, M.M. Evolução geomorfológica da Ibiapaba Setentrional, Ceará: gênese, modelagem e conservação. Tese (Doutorado em Geografia) - Curso de Pós-Graduação em Geografia, Universidade Federal do Ceará, Fortaleza, 2015.

MORAIS NETO J. M.; ALKMIM, F. F. A deformação das coberturas terciárias do Planalto da Borborema (PB-RN) e seu significado tectônico. Revista Brasileira de Geociências. V. 31(1), p. 95-106, 2001.

MORAIS, J. O.; FREIRE, G. S.; PINHEIRO, L. S.; SOUZA, M. J. N.; CARVALHO, A. M.; PESSOA, P. R. S; OLIVEIRA, S. H. M. Ceará. In: Dieter Muehe. (Org.). Erosão e Progradação do Litoral Brasileiro. 154 ed. Brasília: Ministério do Meio Ambiente, 2006.

MOREIRA, A. A. N. Relevo. In: IBGE, Geografia do Brasil: Região Nordeste. Rio de Janeiro: SERGRAF, 1977.

MOURA-LIMA, E.N.; BEZERRA, F. H. R.; LIMA-FILHO, F. P.; DE CASTRO, DAVID L.; SOUSA, MARIA O.L.; FONSECA, V.P.; AQUINO, M. R. 3-D geometry and luminescence chronology of Quaternary soft-sediment deformation structures in gravels, northeastern Brazil. Sedimentary Geology, v. 235, p. 160-171, 2011.

NETO, J. F. L; ROZA, J. B. Projeto Batimetria. ACORDO DE COOPERAÇÃO TÉCNICA ENTRE CPRM EANP / Companhia de Pesquisa de Recursos Minerais - CPRM, 2013.

NEVES, S.P; Granitos Orogênicos: da geração dos magmas à intrusão e deformação. Rio de Janeiro: Synergia, 2012.

NÓBREGA, M. A.; SA, J. M.; BEZERRA, F. H. R.; HADLER NETO, J. C.; IUNES, P. J.; OLIVEIRA, S. G.; SAENZ, C. A. T.; LIMA FILHO, F. P. The use of apatite fission track thermochronology to constrain fault movements and sedimentary basin evolution in northeastern Brazil. Radiation Measurements, Amsterdam, v. 39, p. 627-633, 2005.

PEULVAST, J. P.; VANNEY, J. R. Géomorphologie Structurale. 
Relief et Structure Géologique . Tome 1- Relief at structure. Paris: Collection Géosciences, 2001.

PEULVAST, J.P.; CLAUDINO SALES, V. Aplainamento e geodinâmica: revisitando um problema clássico em geomorfologia. Mercator, v. 1, nº1, p. 113-150, 2002.

PEulvast, J.P., Claudino SAles, V. Carta morfoestrutural do Ceará e áreas adjacentes do Rio Grande do Norte e da Paraíba. In: CPRM, Fortaleza, Atlas digital de geologia e recursos minerais do Ceará. Mapas na escala 1:500.000. Serviço Geológico do Brasil, CD Rom, 2003.

PEULVAST, J. P.; CLAUDINO SALES, V. Stepped surfaces and Paleolandforms in the Northern Brasilian $<$ Nordeste $>$ : Constraints on models of morfotectonic evolution. Geomorphology, v. 3: 89-122, 2004.

PEUlVAST, J. P.; CLAUdinO SAlES, V. Surfaces d'aplanissement et geodinamique. Géomorphologie (Paris) JCR, Paris, v. 4, p. 249-274, 2005.

PEULVAST, J. P.; CLAUDINO-SALES, V.; BEZERRA, F. H. R.; BETARD, F. Landforms and neotectonics in the Equatorial passive margin of Brazil. Geodinamica Acta. v. 19: 51-71, 2006.

PEULVAST, J. P; BÉTARD, F. A history of basin inversion, scarp retreat and shallow denudation: the Araripe Basin as a keystone for understanding long-term landscape evolution in NE Brazil. Geomorphology. v. 233:20-40, 2015.

PILÓ, L.B. Geomorfologia cárstica. Revista Brasileira de Geomorfologia. V.n.1. p. 88-102, 2000.

RADAMBRASIL. FOLHA SB.23/24 JAGUARIBE/NATAL: geologia, geomorfologia. Rio de Janeiro, 1981a.

RADAMBRASIL. FOLHA SB.24 FORTALEZA: geologia, geomorfologia. Rio de Janeiro, $1981 \mathrm{~b}$.

RIOS, V.P.L; AMARO, V.E; VIEIRA, M.M; MATOS, F.M.A; PRUDÊNCIO, M.C; CAMARA, M.C. Influência neotectônica na morfologia do sistema de ilhas barreiras, nordeste do Brasil. Revista Brasileira de Geomorfologia. v 17. n 3, 2016.

ROSS, J. L. S. O registro cartográfico dos fatos geomórficos e a questão da taxonomia do relevo. In.: Revista do Departamento de Geografia, FFLCH-USP,n. 6. São Paulo, 1992.

SILVA, A. J. P.; LOPES, R. C.; VASCONCELOS A. M.; BAHIA,
R. B. C. Bacias sedimentares paleozóicas e meso-cenozóicas interiores. In: Bizzi L. A.; Gonçalves J. H.; Schobbenhaus C.; Vidotti R. M. (eds.) Geologia, Tectônica e Recursos Minerais do Brasil. Brasília: CPRM, 2003.

SOUZA, M. J. N. Contribuição ao estudo das unidades morfoestruturais do Estado do Ceará. Revista de Geologia da UFC. Fortaleza, n. 1, p. 73-91, jun. 1988.

SOUZA, M. J. N. Geomorfologia. In: Atlas do Ceará. Fortaleza: IPLANCE, 1989a. Escala: 1: 500.000.

SOUZA, M. J. N. Hipsometria. In: Atlas do Ceará. Fortaleza: IPLANCE, 1989b. Escala: 1: 500.000.

SOUZA, M. J. N; OLIVEIRA, J. G. B; LINS, R. C; JATOBÁ, L. Condições Geoambientais do semi-árido Brasileiro. Ci. \& Tróp., Recife; v. 20, n. 1, p. 173-198, jan./jun. 1992.

SOUZA, M. J. N. Compartimentação geoambiental do Ceará. In: SILVA, J. B; CAVALCANTE; T. DANTAS, E. (Org). Ceará: um novo olhar geográfico. Fortaleza: Edições Demócrito Rocha, 2007.

TRAVASSOS, L. E. P. Princípios de carstologia e geomorfologia cárstica. 1 ed. Brasília: ICMBio/IABS, 2019.

TRICART, J. Principes et méthodes de la geomorphologie. Paris:Masson Ed., 1965.

TRINDADE, I. V; MARTINS SÁ, J; MACEDO, M. H. F; Comportamento de elementos químicos em rochas mineralizadas em ouro na Faixa Seridó, Província Borborema. Revista Brasileira de Geociências, V38, n2, SP, 2008.

TWIDALE, C.R. Geomorphology. Sydney: Nelson, 2000.

VAsconcelos, A. M.; GOMES, F. E. M. Programa Levantamentos Geológicos Básicos do Brasil - Iguatu (Folha SB.24-Y_B) 1:250.000, Fortaleza: CPRM, 1998.

VAUCHES, A., NEVES, S., CABY, R., CORSINI, M., EGYDIO-SILVA, M., ARTHAUd, M., AMARO, V. The Borborema shear zone system, NE Brazil. Journal of South American Earth Sciences, 8, 1995.

VITAL, H.; AMARO, V.E.; SILVEIRA, I.M. Coastal erosion on the Rio Grande do Norte State (Northeastern Brazil): Causes and factor versus effects associated processes. Journal of Coastal Research, v. 39, p. 1307-1310, 2006. 